\title{
Article \\ A Study on Evaluation of Influencing Factors for Sustainable Development of Smart Construction Enterprises: Case Study from China
}

\author{
Sidong Zhao ${ }^{1, *}$, Ping Zhang ${ }^{2,3}$ and Weiwei Li $^{4}$ \\ 1 School of Architecture, Southeast University, Nanjing 210096, China \\ 2 College of Civil Engineering and Architecture, Jiaxing University, Jiaxing 314001, China; \\ ppqzhangp@zjxu.edu.cn \\ 3 College of Architecture and Urban Planning, Lanzhou Jiaotong University, Lanzhou 730070, China \\ 4 Department of Landscape and Architectural Engineering, Guangxi Agricultural Vocational College, \\ Nanning 530007, China; wwli2021@163.com \\ * Correspondence: sdzhao2018@163.com
}

Citation: Zhao, S.; Zhang, P.; Li, W. A Study on Evaluation of Influencing

Factors for Sustainable Development of Smart Construction Enterprises: Case Study from China. Buildings 2021, 11, 221. https://doi.org/ 10.3390/buildings11060221

Academic Editors: Samad M

E. Sepasgozar and Sara Shirowzhan

Received: 10 April 2021

Accepted: 17 May 2021

Published: 21 May 2021

Publisher's Note: MDPI stays neutral with regard to jurisdictional claims in published maps and institutional affiliations.

Copyright: (c) 2021 by the authors. Licensee MDPI, Basel, Switzerland. This article is an open access article distributed under the terms and conditions of the Creative Commons Attribution (CC BY) license (https:// creativecommons.org/licenses/by/ $4.0 /)$.

\begin{abstract}
Smart construction enterprises are the key subjects in the development and practical transformation of smart building technology, and their sustainable development has been a hot research topic in the new era. In the context of the new round of technology and industrial revolution, the rapid accumulation of development uncertainties and their possible transformation into risks at any time, as well as the ambiguity of growth mechanisms and the loss of strategies, have become major challenges that may constrain the development and strategic management of enterprises. Based on SWOT, BCG, GE, QSPM and principal component analysis methods, this paper constructs a new framework combining theory and practice organically for quantitative identification and evaluation of influencing factors, and analysis of strategy selection and the decision-making process. It will provide a scientific basis for sustainable development and strategic management of smart construction enterprises. DK Company is a typical smart building enterprise in China, and the results of its empirical study show that: Firstly, the 28 variable elements influencing the sustainable development of smart construction enterprises can be summarized into six key factors, with significant differences in their influence, and the external influence far greater than the internal driving force. Secondly, a priority set of six alternatives for strategic decision-making and implementation is proposed, based on the quantitative strategy selection and matching analysis, which improves the accuracy and practicality of the study findings.
\end{abstract}

Keywords: smart construction; smart buildings; strategic planning; influencing factors; China

\section{Introduction \\ 1.1. Background}

The smart building is a typical example of a perfect combination of traditional industries and high-tech industries, which has opened up new development and application fields for information technology, while promoting the development of the construction sector. The integration of building technology with the new generation of information technology, advanced control technology, visualization technology, BIM (building information modeling), artificial intelligence, big data, cloud computing and other emerging technologies has given a new meaning to buildings and opened a new era in the development of building enterprises, the industry and even academic subjects. Smart buildings are bringing revolutionary or even disruptive changes to the whole industry, involving the reconfiguration of factors, modes and relations of production, including the transformation of enterprise technology and management. The process incorporates many academic subjects, such as management science, architecture, civil engineering, and computer science. As an engine for upgrading and innovative development of the construction industry 
in the new era, smart buildings are promoting the transformation of the construction sector from a labor-intensive, traditional form to a technology-intensive, knowledge- and management-intensive emerging industry.

Smart building is committed to providing smart services to users and managers when the building is finished. Smart construction is the whole process of promoting the digitization, networking, visualization, automation and intelligence of building construction, including decision-making, design, production, construction, operation and maintenance, as well as other construction and engineering activities. Smart buildings require enterprises to change the way of construction, and also require changes in the operational model and even industry management theory of the enterprises involved in smart building design, construction, equipment and raw material supply, operation and maintenance, and property management. The high-tech nature and complexity of smart buildings require smart construction enterprises to carry out systematic updating and all-round transformation in technology, talents, equipment, projects, development strategies, operation modes and management philosophy. How to adapt to changes in development environment and construction modes as well as technical methods, so as to seize opportunities actively and cope with threats effectively, has become a new issue facing the sustainable development of smart construction enterprises.

Enterprises are the core subjects of smart construction, and case studies of representative enterprises help to reveal the current characteristics and operational mechanisms of the development of the smart construction industry. How to promote the sustainable development of smart construction enterprises is of interest to policy makers and researchers around the world. Therefore, it is of great theoretical value and practical significance to identify and evaluate the factors influencing the development of smart construction enterprises, to further reveal the growth mechanism of enterprises, and to serve and support the formulation of enterprise development strategies, and thus it draws the common attention from both academic and industry areas.

\subsection{Literature Review}

In recent years, smart buildings have received increasing attention from researchers, with a continuous growth of published papers on the subject. According to the literature, the current research results mainly focus on three topics: The first is research on development, application and evaluation of smart buildings [1], including smart building Internet of Things technology development and application [2-5], smart building's technology network analysis [6], assessment of the cognition of smart building technologies in developing countries [7], and evaluation of the use of 5G technology in smart buildings in developed countries [8]. The second is the design and development of application systems for smart building, including smart building AI ecosystem [9], distributed rule system [10], automation systems [11], driving program and system [12], conceptual framework for operating real-time monitoring and diagnosis system [13], lighting system [14], and rule verification system [15]. The third is the analysis of the performance characteristics and benefits of smart building, including smart building capability and performance indicators [16,17], economic and energy consumption analysis [18], economic feasibility analysis of smart building technology [19], and system [20], data and monitoring analysis [21,22]. In addition, there are a few papers dealing with other areas of research in smart building, including smart building construction, acceptance and maintenance [23,24], application of emerging technologies in industrial construction [25-30], identification of group activity characteristics in smart buildings [31,32], as well as problems and challenges faced by integrating smart buildings into smart cities [33-36].

To sum up, the current academic research on smart buildings has made some achievements, but it is still in a primary stage, with theoretical exploration lagging behind practical needs. Confined to the front-end areas of smart building technology and system development and application, as well as intelligent building characteristics, the existing research is inadequate in the smart building industry and enterprise development, construction 
process and product marketing, technology transformation, application and demonstration, and other back-end areas, which has constrained the expansion of the smart building market space. With the advent of the era of smart buildings, more and more building enterprises come to realize that smart buildings call for a new corporate form and development strategy, and that enterprises can only win new development space by actively getting involved in a new round of innovation, extension, construction and restructuring of the smart building industry chain. Unfortunately, there are only a few exploratory papers in the area of smart building enterprise development, including Measurement of Enterprise Smart Business Performance [37], Smart Home [38,39], Smart Real Estate [40], Smart Agriculture [41], Opportunities for Sustainable Enterprise Development, and Smart City Enterprise Architecture Development [42,43]. The sustainable development practice of smart construction enterprises urgently needs theoretical guidance and case experiences for reference.

\subsection{Aim and Question}

With the continuous emergence and application of new technologies, systems and models for smart buildings and construction, the relationship between different smart construction enterprises and between enterprises and the environment is increasingly complex and changeable, and the factors influencing sustainable development are more numerous and sensitive. The rapid changes in the environment and its increasing uncertainty and complexity have posed huge challenges to the competitiveness, healthy operation and even survival of smart construction enterprises, further threatening the sustainable development of smart buildings and the entire construction industry chain. Therefore, this paper, by studying smart construction enterprises in China, and based on the management and economics-related methods, attempts to analyze the development trends, influencing factors, strategic decisions and implementation plans of Chinese smart construction enterprises and the industry, and tries to reveal their growth mechanisms and their coping strategies, so as to provide a basis for the strategic management of smart building enterprise development and the formulation and implementation of industrial development policies and plans. Specifically, this paper places the focus on the following questions: What are the factors influencing the development of smart construction enterprises in China and how powerful is their influence? How can adaptive strategies be developed for sustainable development of smart construction enterprises in China?

\section{Research Design}

\subsection{Study Area and Enterprise}

\subsubsection{China}

Smart buildings are developing rapidly across the world at present with broad prospects, and smart building technologies and business models are being competitively researched and developed all over the world. According to the Global Smart Buildings Market 2020-2024 report from Technavio, Europe has the largest and most well-developed smart building market, with Germany, UK, France, Belgium, Denmark, Italy, and the Netherlands as its major components; the United States and Canada are the major markets in the Americas, and Brazil, Colombia, and Mexico will see rapid development in the future; the Asia Pacific regions are in the stage of rapid development, and the number of smart buildings in China, India, South Korea, Singapore, and Australia will witness a rapid increase [44]. According to Mordor Intelligence, the smart building market size is forecast to grow at a compound growth rate of over 18.5\% from 2021-2026, with Asia Pacific being the fastest growing region, especially China [45] (see Figure 1). The size of the smart building market in the world's five regions from 2020-2027 was analyzed in the report published by Data Bridge Market Research, with detailed analysis of countries with high levels of smart building development in the regions provided (see Figure 2) [46]. The world smart building market varies greatly in terms of development level and speed of development in general. The development of smart buildings in China is very typical and 
representative in the world, and the case study of China is helpful to discover development experience and academic views of great value.

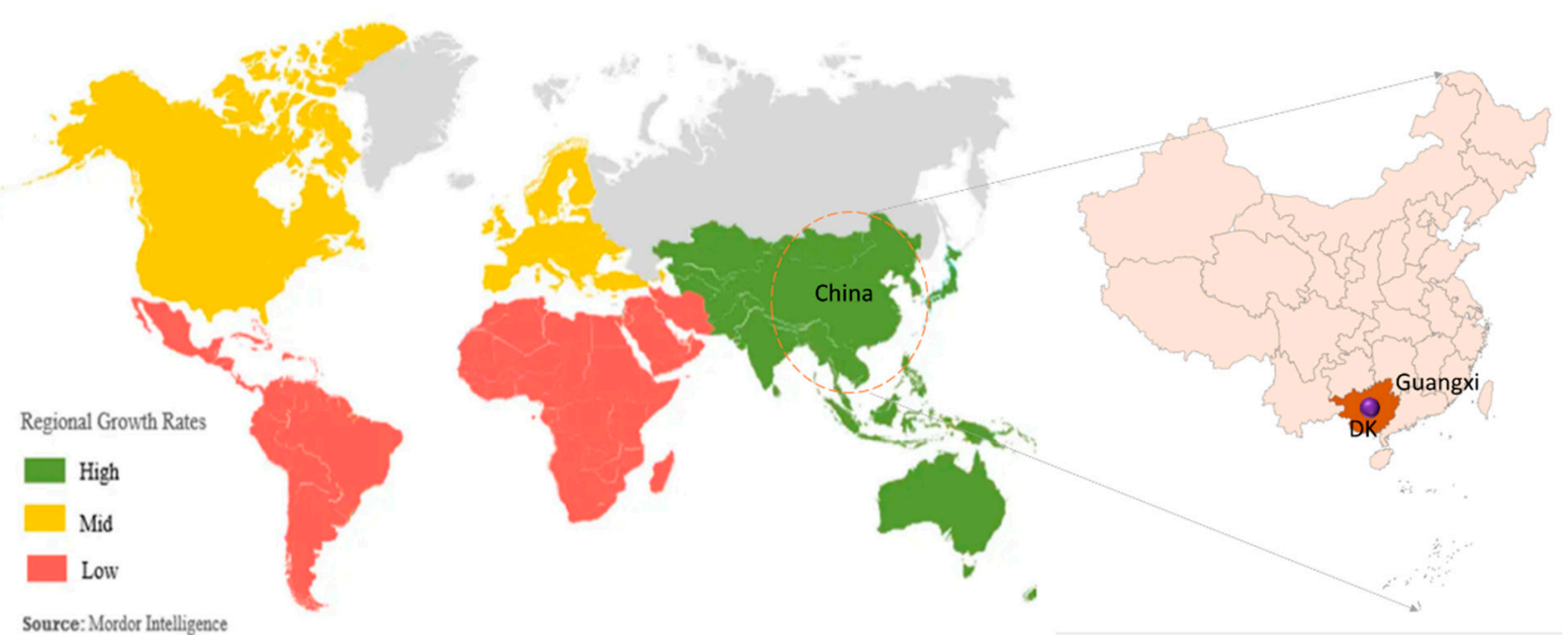

Figure 1. Study area and smart buildings market growth rate by region in the world.

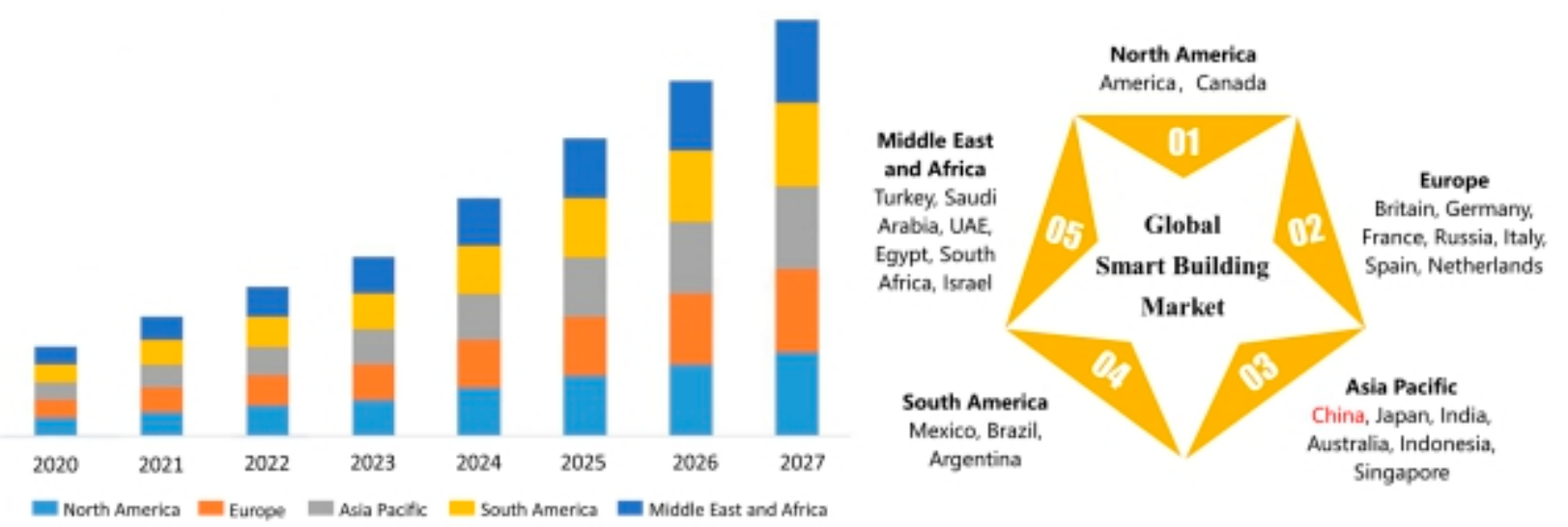

Figure 2. The smart building market size of the regions and countries globally.

The idea of the smart building was first put forward by the Americans, and it started relatively late in China. It was in the early 1990s that China began to introduce the internationally prevalent smart building technology, and in the mid-1990s it was applied exploratively to high-value and important hotels and business buildings. The concept of the smart building was popularized in China until it was applied to large public buildings such as government office buildings, libraries, hospitals, schools, museums, exhibition centers and stadiums by the government. After more than 30 years of development, smart buildings are already common in all types of new constructions in China, with rapid expansion of social demand and market size. In 2019, the smart building market in China reached 921.598 billion yuan ( $¥)$, with a growth of $13.4 \%$; the smart building area was 6.175 billion square meters, up by $11.6 \%$ (see Figure 3). China's current smart buildings still account for less than $40 \%$ of new constructions, lagging far behind developed countries such as the United States, Germany and Japan. Smart buildings still account for a low proportion, with a fast growth but low total volume, mismatching the stage of China's economic and social development. 


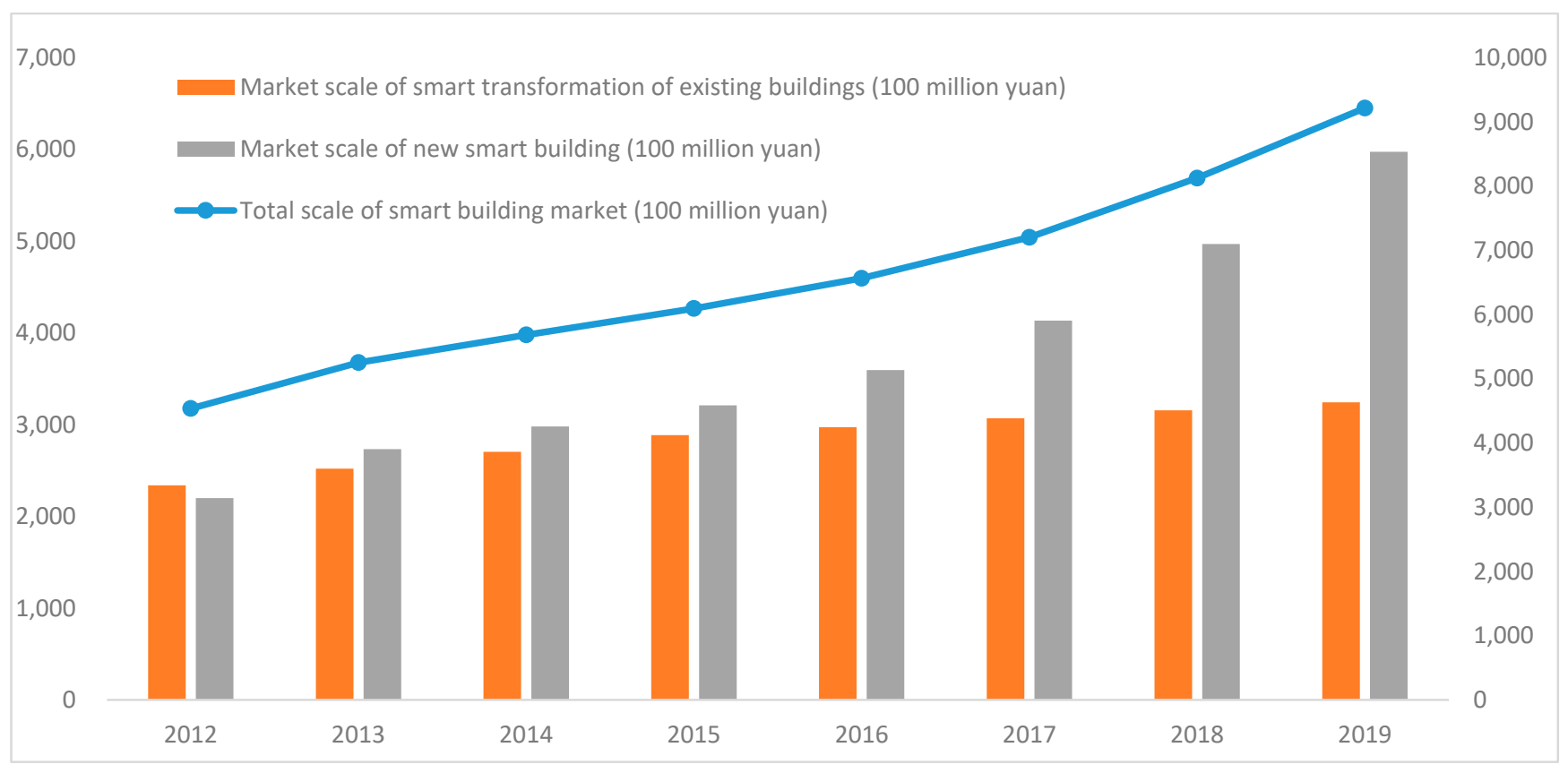

Figure 3. The market size of the smart building in China.

In recent years, China's central and local governments have attached great importance to the development of smart buildings, and have promulgated and implemented relevant policies, requiring construction of new buildings and supporting reconstruction of the existing buildings to be smart, in order to strengthen and expand the smart building market. The General Office of the State Council of China issued and implemented the Opinions on Promoting the Sustainable and Healthy Development of the Construction Industry in 2017, requiring that "smart applications should be promoted and popularized in the construction of new buildings and the reconstruction of existing buildings, and the operation and maintenance mechanism of smart systems should be improved". According to the Guidance on Promoting Collaborative Development of Smart Construction and Construction Industrialization, jointly promulgated and implemented by 13 Chinese national ministries and commissions in 2020, "digitalization and smartness upgrade should be the driving force to increase the application of smartness in all areas of engineering construction, establishing a smart construction industry system that integrates the whole industrial chain covering scientific research, design, production and processing, construction and assembly, and operation".

In summary, due to the typical representativeness of China, the empirical study of the Chinese cases can provide reference for more Asia Pacific countries such as India, Australia, and Indonesia, with great case study value.

\subsubsection{DK Company}

There are currently more than 2000 enterprises with smart building contracting qualifications in China, including more than 800 with Class A qualifications, and about 1000 with Class I contracting qualifications. On the whole, there are a large number of smart construction enterprises in China, but they are small in scale and low in industry concentration. In order to improve the comprehensive competitiveness of China's smart construction enterprises, the Guidance on Promoting Collaborative Development of Smart Construction and Construction Industrialization clearly puts forward a development goal by 2025 for them; to promote the formation of a group of leading smart construction enterprises, lead and drive the transformation and upgrading of small and medium-sized enterprises to smart building, so as to build an upgraded version of "Built in China". 
Founded in 2001, DK is located in Nanning, Guangxi Autonomous Region, China. After nearly 20 years of development, the company has won the honorary titles of "China's Top 100 Smart Building Integrated Enterprise" and "China's Innovative Smart Building Industry Enterprise", and has been a director unit of the Smart Building Branch of China Construction Industry Association, playing a typical role among smart construction enterprises in China. DK is a general contractor of smart construction, a high-tech enterprise in the field of construction industrialization and digitization, specialized in business covering smart construction-related technology development and transfer, software development and design, material production and processing, equipment supply and leasing, general contracting of building construction, building assembly, smart site management and operation, and smart system integration.

DK has more than 100 technical professionals and managers, including over $60 \%$ holding professor titles, senior titles and intermediate titles, and more than $50 \%$ serving as registered construction engineers, registered electrical engineers, registered investment consultants and members with practicing certificates of qualification. DK has developed more than 30 technologies and products with independent intellectual property rights, and has gained six software copyrights, 11 invention patents and utility model patents. DK possesses 13 national and industry qualifications, such as A-level qualification as building intelligent system designer and first-class qualification for professional contracting of electronic and intelligent engineering. It has passed the management system certification of quality, environment and occupational health, and has won more than 10 awards, such as the China Excellent Engineering Survey and Design Industry Award, the China Excellent Construction Electrical Engineering Design Award, the China Installation Engineering Quality Award and the China 100 Building Intelligent Classic Project Award.

DK has achieved diversified development, mainly based on construction business from the perspective of the construction process, supplemented by design business, with stagnation of testing and trading business. In terms of the application range, it mainly focuses on smart buildings, smart communities, smart fire protection, smart city construction, smart parking, smart water utilities, and also engages in smart hospitals, smart municipal services and other businesses occasionally, which are not matured yet. From 2006 to 2020, DK saw an increase of the operating income from 15 million yuan to 230 million yuan, with an average annual growth of about $20 \%$ (see Figure 4). DK has business markets in 22 provinces in China, mainly in East and South China, with high market shares in Guangxi, Jiangsu, Shandong, Hebei and Chongqing (see Figure 5). As a leading regional provider of integrated solutions for smart construction and building industrialization, DK provides business services covering a variety of different building and engineering projects such as offices, residences, hospitals, schools, airports, bridges, highways, railroads and multi-purpose networks for pipelines in cities. 


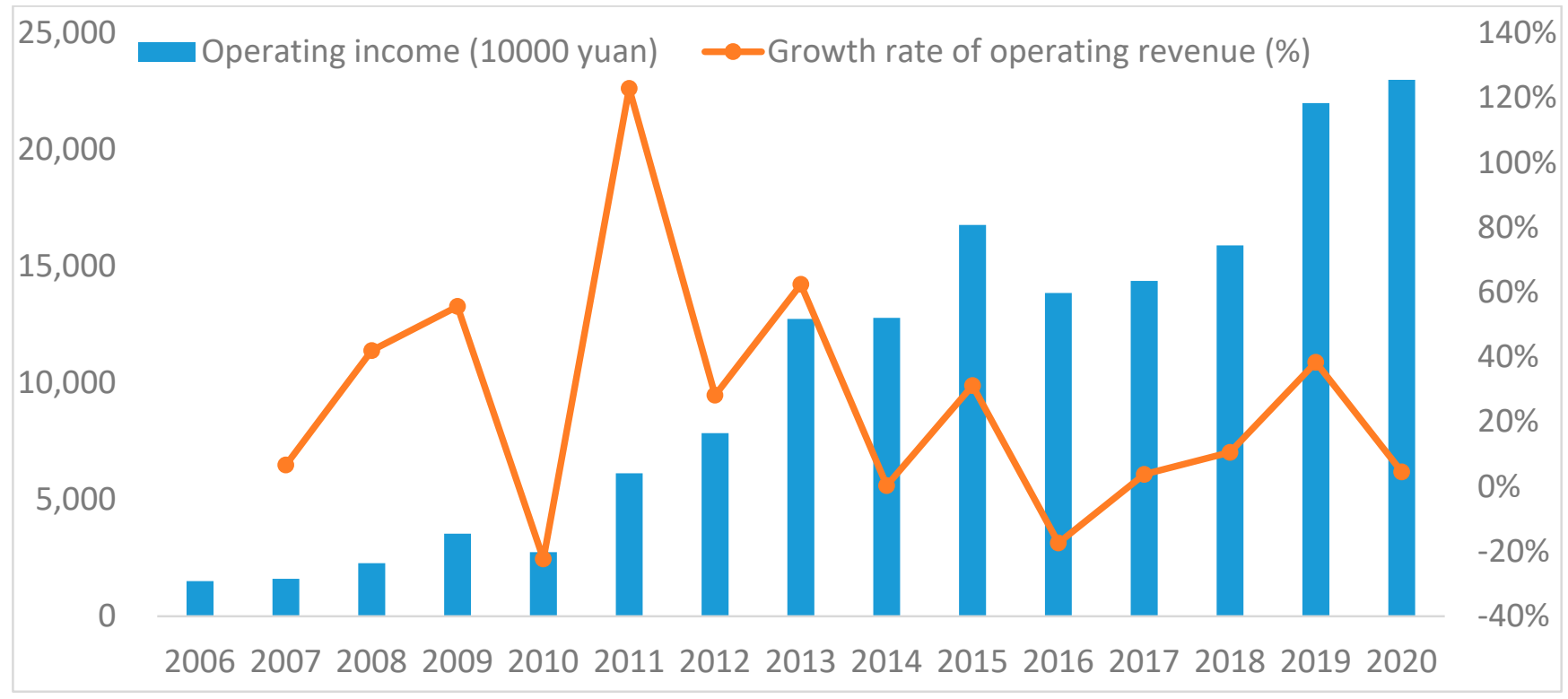

Figure 4. Analysis on the operating income change of DK company.
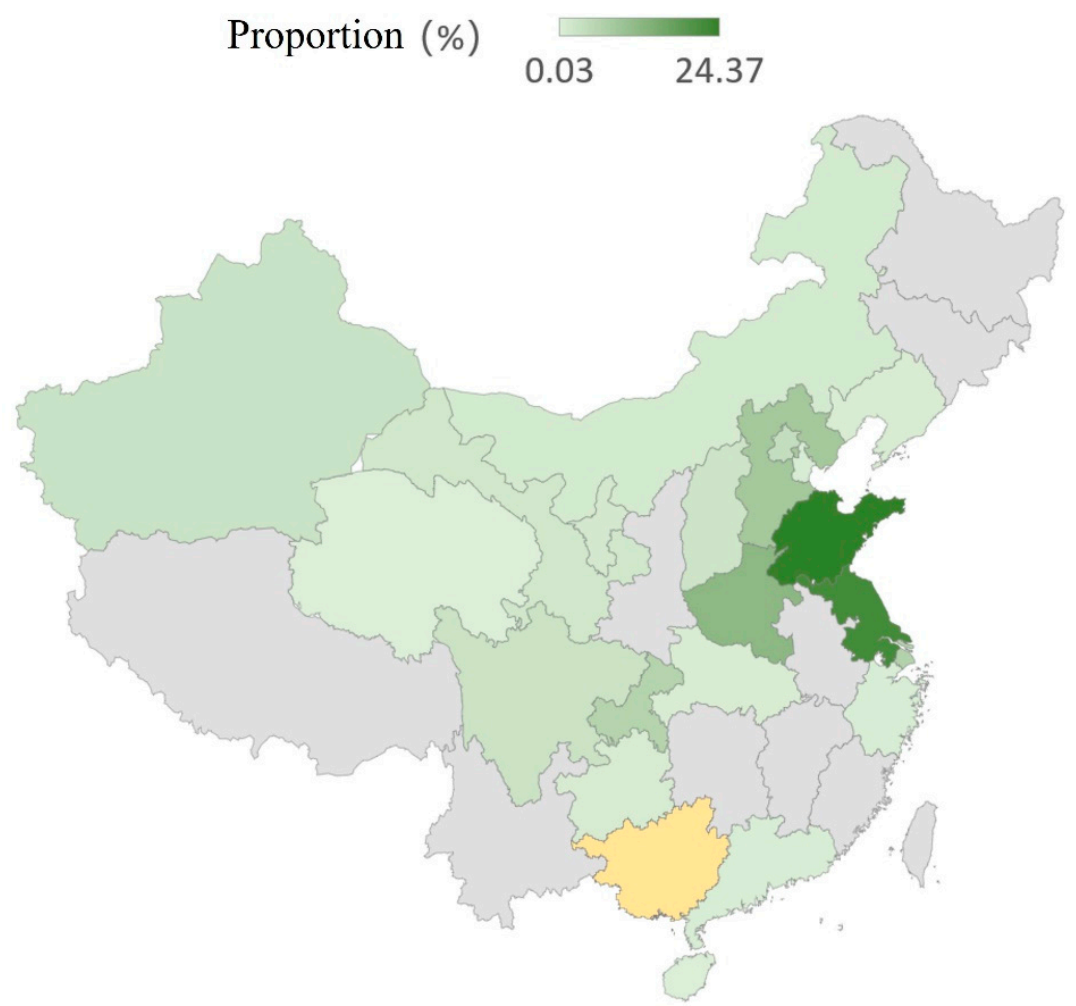

Figure 5. Analysis on the market spatial distribution of DK company in China. 


\subsection{Research Methods}

\subsubsection{Method Evaluation and Selection}

The influence of established results on the sustainable development of enterprises is mainly studied in terms of both exogenous and endogenous factors. The exogenous factor theory holds that an enterprise can adapt to the external environment and take advantage of external opportunities to achieve growth, while the endogenous factor theory regards the resources and capabilities within the enterprise as the decisive factors to promote its growth. Theories of the business enterprise strategic management and development economics have currently proposed strengths-weaknesses-opportunities-threats (SWOT), political-economic-social-technological (PEST), Boston Consulting Group (BCG), General Electric (GE), Porter's five forces model (PFFM), quantitative strategic programming matrix (QSPM) and many other analytical tools, and they are widely used in the evaluation of enterprise development factors, strategic management, industrial and even regional development planning formulation and implementation.

Existing academic papers show that SWOT is most commonly used, while PEST, PFFM, BCG and other methods are rarely applied. SWOT is widely used in the study of development strategies and sustainable development planning of traditional industries, such as the fishmeal industry [47], the cherry industry [48], the paper industry [49], the mining industry [50-52], the textile industry [53,54], the coal chemical industry [55], the ceramics industry [56], and the compressed natural gas industry [57]; it is also commonly applied to assess influencing factors and competitiveness of emerging industries, such as Industry 4.0 [58], the e-commerce industry [59], the cultural industry [60,61], the wind power industry [62], the new-energy automobile industry [63], and the machine tool industry [64]. PEST has been applied to the development environment analysis of the waste-to-energy anaerobic digestion industry [65], the bio-energy industry [66] and other industries. PFFM has been used in the study of pricing strategies of low-cost airlines [67] and in the analysis of competitive dynamics in the shale gas and robotics industries $[68,69]$, while BCG and QSPM have been applied in the coffee export market and ecotourism, and in the formulation of small enterprise development strategy planning [70,71], respectively. SWOT has also been applied in the construction industry, including the analysis and strategic assessment of critical success factors for the use of BIM [72-75], cloud computing [76], e-procurement [77], and smart devices [78], as well as the strategic choice of the construction industry [79-81], building energy efficiency [82,83], and quality management of construction enterprises [84].

To sum up, SWOT has been a common tool to analyze influencing factors and development strategies, and PEST, PFFM, BCG, QSPM, etc. have also been used to some extent. However, there are still some deficiencies in the current research. On the one hand, there is no research on the factors influencing the sustainable development of smart construction enterprises and the countermeasures, and there are very few results of empirical research on the integrated application of PEST, PFFM, BCG, QSPM and other tools in the construction industry; on the other hand, in the papers applying SWOT, only a few methods such as AHP and QSPM are used in combination, mainly in qualitative research, and there are very few research results integrating SWOT with PEST, PFFM, BCG, GE, QSPM and other analysis tools. The lack of quantification and crossover in the era of big data has adversely affected the accuracy of research results and the practicality of conclusions.

\subsubsection{Cross Application and Quantification of Multiple Methods}

(1) Qualitative analysis

SWOT, based on a comprehensive assessment of internal conditions and external environment and a comprehensive pairing analysis of strengths, weaknesses, opportunities and threats, helps to select the best development strategy. Internal conditions can be further decomposed into resources and capabilities for analysis. The former includes capital, equipment, manpower, organization, qualification, technology, brand, tacit knowledge and social relations, while the latter involves financial capabilities, marketing capabilities, production management capabilities, organizational effectiveness and corporate culture. The external 
environment includes macro-environment and industry environment, which can be further decomposed by PEST and PFFM models, respectively. Based on the SWOT pairing analysis, $\mathrm{SO}, \mathrm{WO}, \mathrm{ST}$, and WT alternative strategy options can be accessed (see Figure 6).

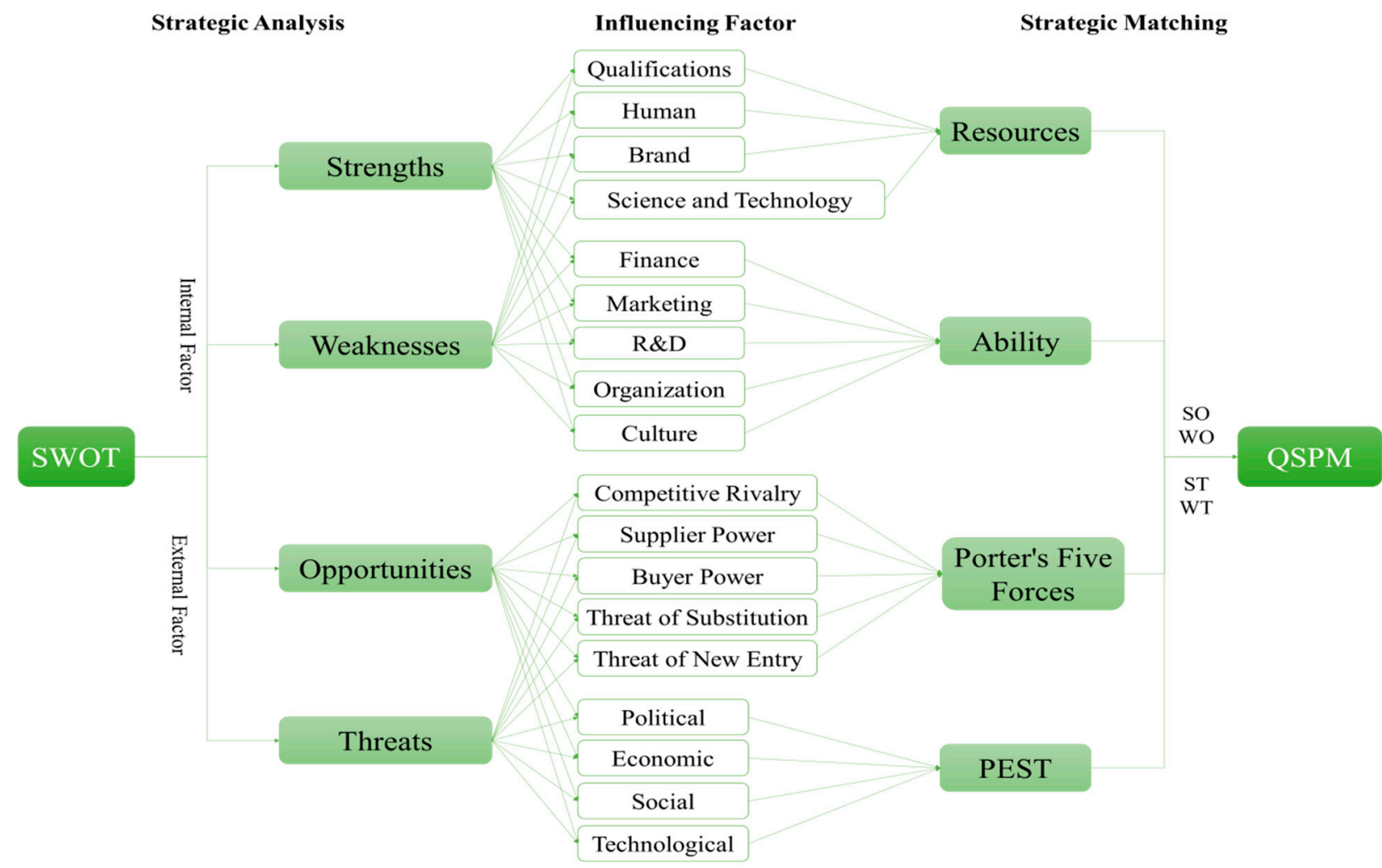

Figure 6. Research framework and methods.

(2) Quantitative analysis

By decomposing the principal influencing factors, survey questions are designed as research variables. With the results of a questionnaire survey, the variables can be graded and assigned a score. Firstly, the key influencing factors of sustainable development of smart construction enterprises can be extracted and summarized by using variable values based on principal component analysis, factor analysis and other methods. Secondly, the intensity of overall strengths, weaknesses, opportunities and threats can be calculated based on the weighted sum of the variables, and the strategic choice quadrilateral can be made accordingly. According to the quadrant of the strategy quadrilateral center of gravity, it is possible to identify the optimal strategy that the enterprises should theoretically adopt, based on the equation as follows:

$$
\begin{gathered}
S=\sum_{i=1}^{n} W_{i} \times S_{j}^{\prime} \quad(i, j=1,2,3 \ldots \ldots, n) \\
W=\sum_{i=1}^{n} W_{i} \times W^{\prime}{ }_{j(i, j=1,2,3 \ldots \ldots, n)} \\
O=\sum_{i=1}^{n} W_{i} \times O^{\prime}{ }_{j(i, j=1,2,3 \ldots \ldots, n)} \\
T=\sum_{i=1}^{n} W_{i} \times T^{\prime}{ }_{j(i, j=1,2,3 \ldots \ldots, n)}
\end{gathered}
$$




$$
P(x, y)=\left(\frac{S+W}{4}, \frac{O+T}{4}\right)
$$

$S$ and $S^{\prime}{ }_{j}$-Strengths and the score of each respondent's evaluation.

$W$ and $W^{\prime}{ }_{j}$-Weaknesses and the score of each respondent's evaluation.

$\mathrm{O}$ and $\mathrm{O}^{\prime}{ }_{j}$-Opportunities and the score of each respondent's evaluation.

$T$ and $T^{\prime}{ }_{j}$ - Threats and the score of each respondent's evaluation.

$W_{i}$-The weight of each question item in the questionnaire.

$P(x, y)$ - The center of gravity coordinates of the strategic quadrilateral.

$i$ and $j$-The number of question item and respondent.

Smart construction companies generally take a diversified approach to their operations, with different business development levels. There are also large differences in the commitment to implementation and execution of alternative strategy options among managers and employees of different companies. Thus, the theoretically optimal strategy may not be the best option for an enterprise in practice, and, in special circumstances, it may be the worst one. Based on the QSPM matrix evaluation method [85] and the investigation on enterprise managers and key employees, the relative attractiveness scores (ASs) of variables can be accessed, and the total attractiveness scores (TASs) of alternative strategy options can be calculated by further weighting the sum to access the priority set of alternative strategy options.

\subsection{Research Steps}

The first step is selection of key influencing factors. The key factors influencing the sustainable development of the enterprise, including macro development environment in China, intelligent building industry environment, DK's resources and capabilities, are put forward by using SWOT, PEST and PFFM in combination (see Figure 7).

The second step is data collection. A questionnaire is designed based on key influencing factors (see Tables A1 and A2) and DK employees, customers, suppliers, competitors, industry experts and government officials are invited to fill out the questionnaire via WeChat and QQ (see Table A3). Firstly, questions are used as variables after collection of the questionnaire for principal component analysis [86], to extract and summarize the key factors influencing sustainable development of smart construction enterprises. Secondly, the weighted scores of variables are calculated, and the total scores of strengths, weaknesses, opportunities, and threats can be calculated according to Equations (1)-(4). Thirdly, the strategy quadrilateral is made, and the coordinates of the center of gravity are calculated according to Equation (5) to put forward the theoretically optimal strategy.

The third step is the alternative strategy matching analysis. Based on the analysis results of SWOT, GE and BCG, alternative strategy options such as SO, WO, ST and WT are put forward. Managers and key employees of DK are invited to conduct interviews and surveys on the implementability of alternative strategy options and to evaluate strategic decisions based on the QSPM matrix. Alternative strategy ASs and TASs are calculated to analyze the feasibility and operability of alternative strategy options and thus obtain a strategy priority set. 


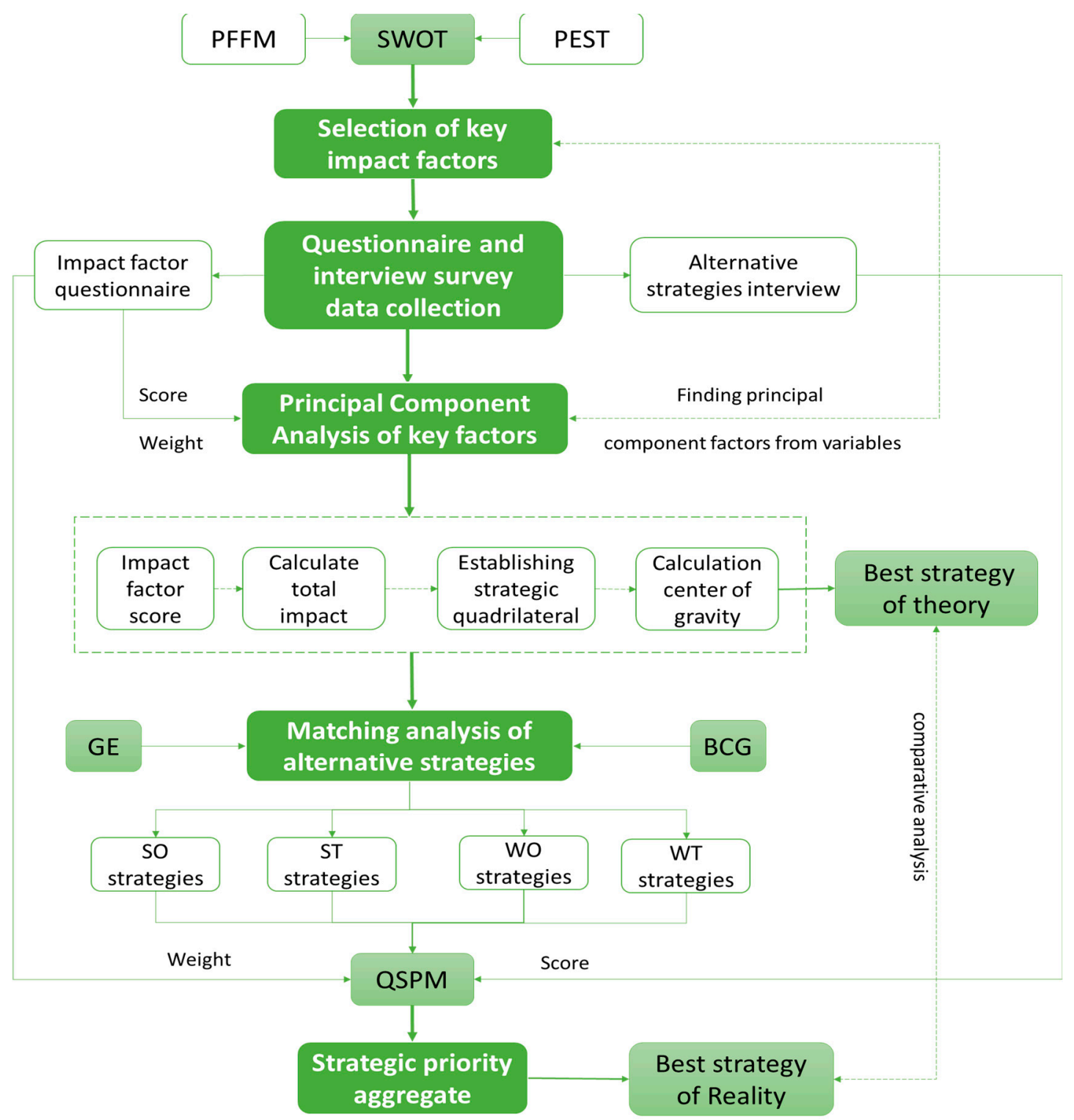

Figure 7. Research steps.

\subsection{Data Sources and Processing}

\subsubsection{Data Sources}

The industry data in this paper are mainly from the China Statistical Yearbook released by the Chinese National Bureau of Statistics, the 2020-2026 China Smart Building Industry Market Comprehensive Research and Investment Prospect Forecast Report released by ibaogao.com, DK's annual statistical reports, questionnaire data (Table A3) as well as interview and research data.

\subsubsection{Questionnaire Design}

In addition to four questions about identity information, DK designed a total of 35 professional questions in the questionnaire as 35 variables to analyze the influencing factors. The questions were designed based on SWOT as the core framework, in combination with IFE, EFE, PEST, and Michael Porter's five forces model (Tables A1 and A2). The influence of variables in the questionnaire on DK was divided into two types; favorable and unfavorable, expressed by positive and negative numbers, respectively. According to the Likert scale, influence was divided into five levels and they were represented by 
the numbers $1-5$, with higher values representing more strengths and opportunities and greater constraints of weaknesses and threats.

\subsubsection{Questionnaire Analysis}

A total of 300 paper and electronic questionnaires were distributed from May 2020 to March 2021, and 247 were collected, accounting for $82 \%$. There were 216 valid questionnaires, accounting for $87 \%$. Most of the respondents were in a certain interest relationship with DK generally, and there was a large proportion who were highly educated with high-ranking titles and positions. They were the most vocal people and they had a deeper understanding of DK and the smart building industry, so their feedback was more credible (see Figure 8).
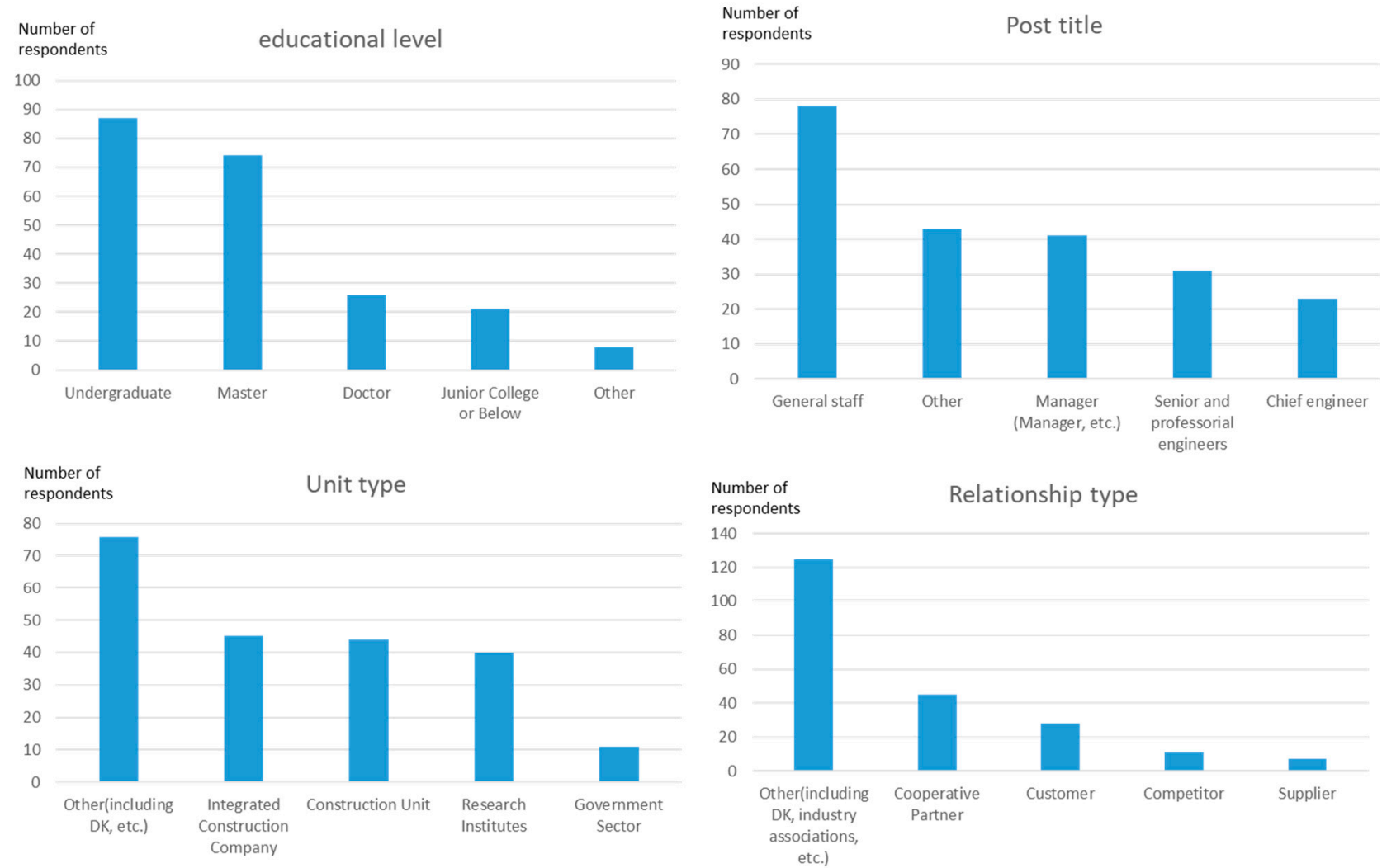

Figure 8. Number of respondents according to the level of education, post title, unit type and relationship type.

Reliability, validity, weights and other parameters were calculated based on an online tool SPSSAU online tool [87]. Cronbach $\alpha$ reliability coefficient was 0.826 , greater than 0.8 ; Spearman-Brown split-half reliability coefficient was 0.754 , between $0.7-0.8$, indicating the high quality of the reliability of the data from this questionnaire [88]. The KaiserMeyer-Olkin (KMO) value was 0.925 , greater than 0.8 , indicating that the validity of the research data was very good. The chi-square value of Bartlett's sphericity test was 3678.952, with a degree of freedom of 595 and a significance probability (Sig.) of 0.000, which is less than 0.001 , indicating that the correlation matrix is not unitary, rejecting 0 hypothesis and making it suitable for principal component factor analysis [75]. The weights were calculated by the precedence chart method in the online tool SPSSAU [89]. 


\section{Results}

\subsection{Principal Component Analysis of Key Factors}

\subsubsection{Factor Number Analysis}

Using statistical analysis based on SPSSAU, Cattel scree plot and variance contribution ratio table for the impact factors (i.e., 35 variables) of sustainable development of smart construction enterprises in China can be established. The scree plot is a visual graph of factor extraction, with the number of variables as horizontal coordinates and the eigen-roots as vertical coordinates. According to screen test, the variables at the bottom of the curve steep slope are not of importance. The number of principal component factors extracted can be judged by observing the slope of each variable's eigenvalue and the value taken. From Figure 9, it can be seen that the curve slope from the first to the sixth variable is steep and the eigenvalue is greater than 1 . Starting from the seventh variable, the curve tends to be flat with the eigenvalue of less than 1 . Therefore, the number of principal component factors extracted is six. Table 1 shows that the cumulative contribution of the total variance of the six principal components reached $58.269 \%$. In view of the actual research, it can be considered that these six principal components well represent the overall information of the sample in this study.

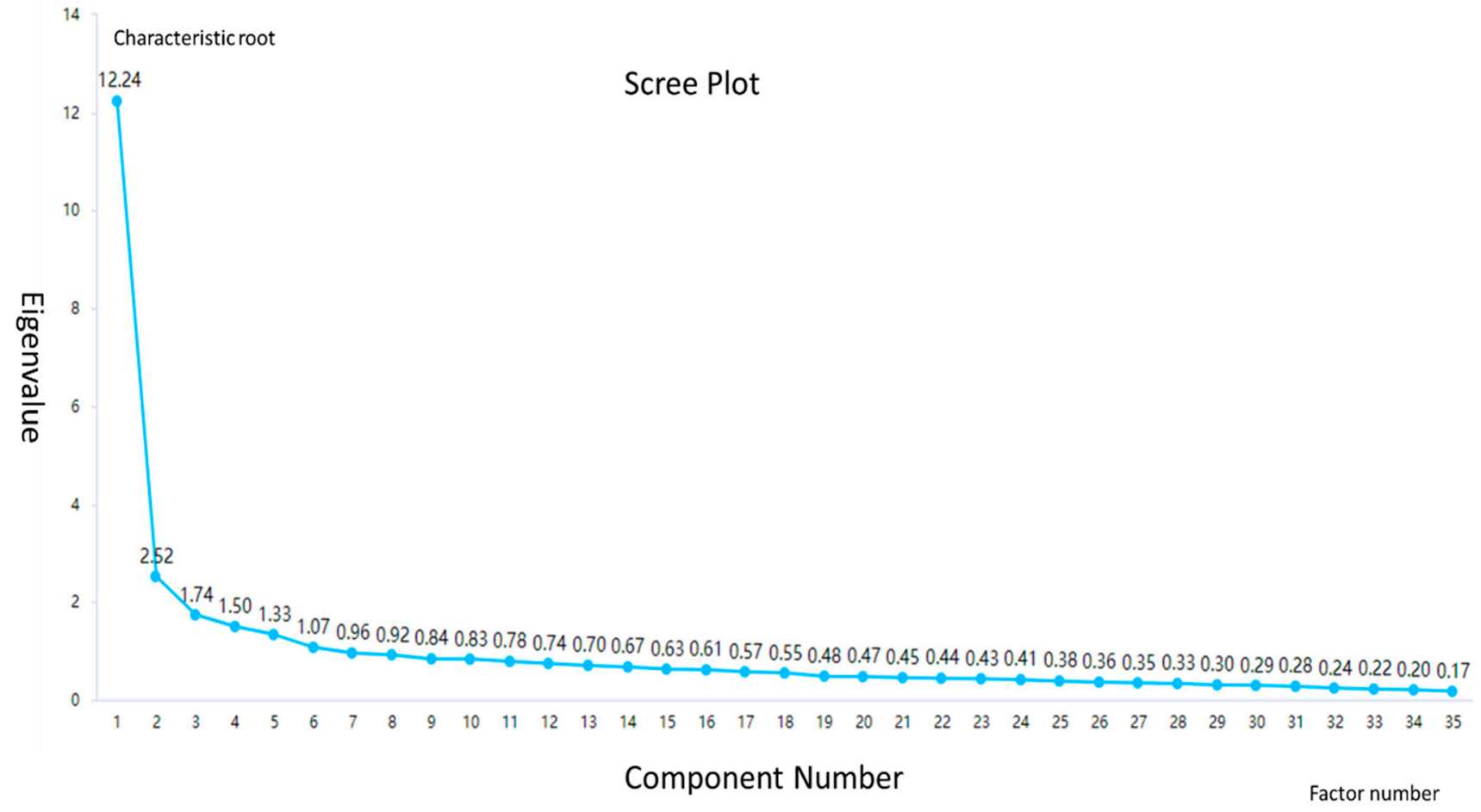

Figure 9. Eigenvalues for ordered factors of DK.

Table 1. The variance explanation of factor.

\begin{tabular}{ccccccc}
\hline \multirow{2}{*}{ Factors } & \multicolumn{2}{c}{ Extraction Sums of Squared Loadings } & \multicolumn{2}{c}{ Rotation Sums of Squared Loadings } \\
\cline { 2 - 7 } & Total & \% of Variance & Cumulative \% & Total & \% of Variance & Cumulative \% \\
\hline 1 & 12.237 & 34.964 & 34.964 & 12.237 & 34.964 & 34.964 \\
2 & 2.52 & 7.2 & 42.163 & 2.52 & 7.2 & 42.163 \\
3 & 1.737 & 4.962 & 47.125 & 1.737 & 4.962 & 47.125 \\
4 & 1.497 & 4.277 & 51.403 & 1.497 & 3.277 & 55.209 \\
5 & 1.332 & 3.807 & 55.209 & 1.332 & 3.06 & 58.269 \\
6 & 1.071 & 3.06 & 58.269 & 1.071 & 3.06 & \\
\hline
\end{tabular}




\subsubsection{Factor Composition Analysis}

Common degree is common factor variance, which is an index to measure the effect of variable analysis, and it depicts the degree to which all principal component factors explain the information of the variable. Principal component analysis was performed based on SPSSAU to obtain the eigen-roots and loading coefficients of the factors (see Table 2). Table 2 shows that the common degree of all the other variables, except for the two special variables 10 and 28 , is greater than 0.4 , indicating that the principal component factors are better in explaining the variance of variables. Although the common degree value of variable 10 was greater than 0.4 , none of the principal component factors worked well in explanation. Although the load coefficient of variable 28 reached 0.499 in Factor 3, its common degree value was less than 0.4 . Without the deletion of variables, variables 10 and 28 can only barely be classified as Factor 1 and 3 . When extracting the variables of principal component factors, variables $2,6,11,15,19,20,21,22,27,28,31,33$ and 34 can theoretically be classified as multiple principal component factors. Therefore, a comprehensive analysis of their loading coefficients and their relationships with the variables must be performed to finally develop the solution in Table 2 . The six principal component factors are described as follows:

Table 2. The Rotated Component Matrix.

\begin{tabular}{|c|c|c|c|c|c|c|c|}
\hline \multirow{2}{*}{ Factors } & \multicolumn{6}{|c|}{ Principal Component } & \multirow{2}{*}{$\begin{array}{c}\text { Commor } \\
\text { Degree }\end{array}$} \\
\hline & Factor 1 & Factor 2 & Factor 3 & Factor 4 & Factor 5 & Factor 6 & \\
\hline 1 & 0.537 & 0.34 & 0.191 & 0.138 & 0.138 & 0.058 & 0.483 \\
\hline 2 & 0.458 & 0.473 & 0.22 & -0.055 & 0.132 & -0.097 & 0.512 \\
\hline 3 & 0.624 & 0.196 & 0.254 & 0.302 & -0.033 & -0.052 & 0.587 \\
\hline 4 & 0.621 & 0.248 & 0.165 & 0.147 & 0.184 & -0.078 & 0.536 \\
\hline 5 & 0.578 & 0.248 & 0.181 & 0.369 & 0.042 & 0.027 & 0.567 \\
\hline 6 & 0.611 & 0.174 & 0.068 & 0.439 & 0.221 & -0.035 & 0.65 \\
\hline 7 & 0.557 & 0.04 & 0.143 & -0.023 & 0.343 & 0.134 & 0.469 \\
\hline 8 & 0.68 & 0.274 & -0.086 & 0.187 & 0.074 & 0.364 & 0.718 \\
\hline 9 & 0.736 & 0.212 & -0.049 & 0.023 & 0.023 & 0.391 & 0.742 \\
\hline 10 & 0.362 & 0.14 & 0.333 & 0 & 0.187 & 0.336 & 0.409 \\
\hline 11 & 0.407 & -0.02 & 0.126 & 0.211 & 0.457 & 0.32 & 0.537 \\
\hline 12 & 0.214 & 0.084 & 0.194 & 0.08 & 0.716 & 0.088 & 0.618 \\
\hline 13 & 0.04 & 0.314 & 0.154 & 0.184 & 0.667 & 0.137 & 0.621 \\
\hline 14 & 0.128 & 0.164 & 0.199 & 0.074 & 0.706 & 0.171 & 0.615 \\
\hline 15 & 0.316 & 0.012 & 0.171 & 0.507 & 0.281 & 0.422 & 0.644 \\
\hline 16 & 0.138 & 0.214 & 0.18 & 0.285 & 0.333 & 0.56 & 0.603 \\
\hline 17 & 0.058 & 0.182 & 0.115 & 0.014 & 0.158 & 0.712 & 0.582 \\
\hline 18 & 0.347 & 0.195 & 0.125 & 0.526 & 0.045 & 0.269 & 0.525 \\
\hline 19 & 0.255 & 0.415 & 0.128 & 0.609 & 0.175 & 0.034 & 0.656 \\
\hline 20 & 0.241 & 0.534 & 0.179 & 0.538 & 0.127 & 0.011 & 0.681 \\
\hline 21 & 0.323 & 0.526 & 0.125 & 0.462 & 0.129 & 0.123 & 0.642 \\
\hline 22 & 0.236 & 0.515 & 0.248 & 0.431 & 0.06 & 0.106 & 0.583 \\
\hline 23 & 0.171 & 0.628 & 0.138 & 0.045 & 0.096 & 0.185 & 0.488 \\
\hline 24 & 0.185 & 0.616 & 0.101 & 0.366 & 0.045 & 0.199 & 0.6 \\
\hline 25 & 0.151 & 0.734 & 0.032 & 0.078 & 0.107 & 0.232 & 0.634 \\
\hline 26 & 0.207 & 0.736 & 0.082 & 0.117 & 0.148 & -0.005 & 0.626 \\
\hline 27 & 0.191 & 0.407 & 0.51 & 0.061 & 0.228 & 0.177 & 0.55 \\
\hline 28 & 0.285 & 0.037 & 0.499 & 0.091 & 0.023 & 0.228 & 0.392 \\
\hline 29 & 0.144 & 0.061 & 0.734 & 0.176 & 0.134 & 0.005 & 0.612 \\
\hline 30 & 0.146 & 0.088 & 0.684 & 0.188 & 0.143 & -0.004 & 0.552 \\
\hline 31 & 0.137 & 0.038 & 0.578 & 0.486 & 0.159 & 0.157 & 0.64 \\
\hline 32 & -0.031 & 0.273 & 0.69 & -0.149 & 0.139 & 0.137 & 0.612 \\
\hline 33 & -0.002 & 0.048 & 0.519 & 0.455 & 0.317 & 0.111 & 0.592 \\
\hline 34 & -0.105 & 0.196 & 0.427 & 0.411 & 0.044 & 0.444 & 0.599 \\
\hline 35 & 0.17 & 0.133 & 0.377 & 0.303 & 0.229 & 0.428 & 0.516 \\
\hline Total & 5.713 & 4.228 & 3.695 & 2.539 & 2.089 & 2.122 & - \\
\hline
\end{tabular}

Note: Red represents $>0.4$, purple represents special variables, and gray shading represents that the variable should be classified as a principal component factor in the column. 
Factor 1 is the endogenous development factor of the enterprise, and its variables in terms of influence are ranked as $9>8>3>4>6>5>7>1>11>10$, with a total loading coefficient of 5.713. (The total loading coefficient is equal to the sum of the influence of the four variables. The following factors $2-6$ have the same meaning.) It mainly involves the resources and capabilities of DK, where the characteristic products and technologies, the innovation ability of technology and products, the relationship with shareholders, the degree of business diversification and the quality of customer service have a large load coefficient (greater than 0.6). The main characteristics of these variables can be summarized by the endogenous development factors of enterprises, indicating that the level of enterprise operation and management is the key factor influencing the sustainable development of smart construction enterprises in China at the present stage.

Factor 2 is the market and industry chain factor, and its variables in terms of influence are ranked as $26>25>23>24>21>22>2$, with a total loading coefficient of 4.228 . It mainly involves the development trend and market demand of the smart building industry as well as factors related to the upstream and downstream of DK's industry chain of DK, where the smart building technology level, the social recognition of the smart building, the growth rate of the market demand and the development prospect of the smart building have a large loading coefficient (greater than 0.6). The main characteristics of these variables can be summarized by the smart building market and industry chain factors, indicating that the market size and demand, and the overall level of industry chain development, are the key factors influencing the sustainable development of smart construction enterprises in China at the present stage.

Factor 3 is the macro-environment and competition factor, and its variables in terms of influence are ranked as $29>32>30>31>27>28$, with a total loading coefficient of 3.695. It mainly involves the macro-economic and social development environment as well as the related factors of enterprise competition, where the entry barrier of potential entrant, enterprise competition intensity and the national macro-economic development have a large load coefficient (greater than 0.6). The main characteristics of these variables can be summarized by the macro-environment and competition factors, indicating that the national macro development stage and competition degree are the key factors influencing the sustainable development of smart construction enterprises in China at the present stage.

Factor 4 is the policy and customer demand factor, and its variables in terms of influence are ranked as $19>20>18>33>34$, with a total loading coefficient of 2.539. It mainly involves policies and plans about smart city, smart construction, new infrastructure and smart building, as well as factors influencing DK's major customers and new customers, where the loading coefficient of smart city and smart construction policies is greater than 0.6 , and the compliance coefficient of new infrastructure policies and smart building plans is greater than 0.5 . The main characteristics of these variables can be summarized by the policy and customer factors, indicating that the national macro development stage and competition degree are the key factors influencing the sustainable development of smart construction enterprises in China at the present stage.

Factor 5 is the funding and goodwill factor, and its variables in terms of influence are ranked as $12>14>13$ with a total loading coefficient of 2.089. It mainly involves influencing factors such as DK's capital, brand, and industry status, and the loading coefficients of the three variables are large, all greater than 0.6. The main characteristics of these variables can be summarized by the capital and goodwill factors of enterprises, indicating that the capital adequacy and corporate image of enterprises are the key factors influencing the sustainable development of smart construction enterprises in China at the present stage.

Factor 6 is the talent and innovation factor, and its variables in terms of influence are ranked as $17>16>35>15$, with a total loading coefficient of 2.122, slightly larger than that of Factor 5. It mainly involves influencing factors such as threat of substitutes, patent and software copyright as well as talent reserve and product standardization, where the loading coefficient of patent and software copyright reserve is greater than 0.6 and that of talent reserve is greater than 0.5 . The main characteristics of these variables can 
be summarized by the talent and innovation factors of enterprises, indicating that the talent and intellectual property reserves and the threat of substitutes are the key factors influencing the sustainable development of smart construction enterprises in China at the present stage.

\subsection{Best Strategy Analysis}

\subsubsection{Alternative Strategy Options Analysis}

From the overall level of company development, four alternative strategy options of SO, $\mathrm{WO}, \mathrm{ST}$ and WT can be accessed by comprehensive analysis of SWOT. From the perspective of business development, as a comprehensive enterprise, DK has significant differences in business development levels, and it is necessary to further subdivide its overall strategy. CJS is the largest competitor of DK, with a substantially similar business structure. The market growth is measured by the increase of the main business income of DK, and the multiple of the business income of DK and CJS is used to measure the relative market share. Based on the comprehensive analysis of the main business and regional market development trend of DK by SWOT, BCG (CJS being its biggest competitor) and GE in combination, six alternative strategy options can be accessed (see Table 3 and Figure 10) as follows:

(1) Market penetration strategy: expand customer network and market space. Efforts should be made to expand market share in the current market space and to achieve a further increase in the company's market share relying on the existing business, that is, in order to expand the existing customer network and the market space. From the perspective of business, DK should give priority to the expansion of smart city construction and maintain or moderately expand the smart building market size. From the perspective of customer network, DK should focus on expanding the top 10 customers, especially making good use of the business relationship network of shareholder companies. From the perspective of the geographical market, DK should give priority to expanding the market size in prefecture-level cities such as Liuzhou, Nanning and Yulin and provinces such as Jiangsu, Shandong, Chongqing, Hebei, Beijing, Shanxi and Xinjiang.

(2) Market development strategy: cultivate new customers and new regional market. Measures should be taken to put the original products and solutions into new markets to achieve a sustainable increase in the company's business income. DK should increase capital investment in new customer expansion and new market exploitation, and prioritize the cultivation of new customers by taking advantage of the relationship networks of shareholder companies and major customers, with a focus on developing blank markets in prefecture-level cities such as Hezhou, Hechi, Chongzuo and Fangchenggang, and provinces such as Yunnan, Jiangxi, Anhui and Fujian.

(3) Cooperation strategy: joint venture and horizontal integration. For business areas and market geographies with greater development opportunities and disadvantages, new markets and businesses should be cultivated with the help of cooperation and horizontal integration models. DK should give priority to the establishment of strategic partnerships, consortia, alliances or joint ventures to promote the development of smart neighborhoods, smart firefighting and other child businesses, and develop new growth points by cooperating with local companies in Fujian, Anhui and other geographical markets.

(4) Business expansion strategy: vertical integration. Measures such as external mergers, acquisitions, joint ventures and new internal business units should be taken to promote the extension of the company's main business into the upstream and downstream of the supply chain and the industrial chain. DK should, relying on its predominant businesses such as smart buildings and smart communities, extend to the upstream businesses such as equipment supply, system design and technology development of smart buildings, and expand to the downstream businesses such as construction, operation and maintenance, and property management of smart buildings. 
(5) Harvest strategy: control investment. The harvest strategy requires controlling business investment scale and cutting all expenses to improve the company's total cash flow. This strategy is appropriate for the smart building business of DK.

(6) Abandonment strategy: divestiture and liquidation. For businesses or markets where the harvest strategy is not working, the unprofitable part should be abandoned to cut loss in time. DK's Dog businesses, such as smart parking and smart water utilities, should be phased out and recovered at the right time, and no additional investment should be made in Ningxia, Qinghai, Sichuan, Liaoning, Inner Mongolia and other Dog markets.
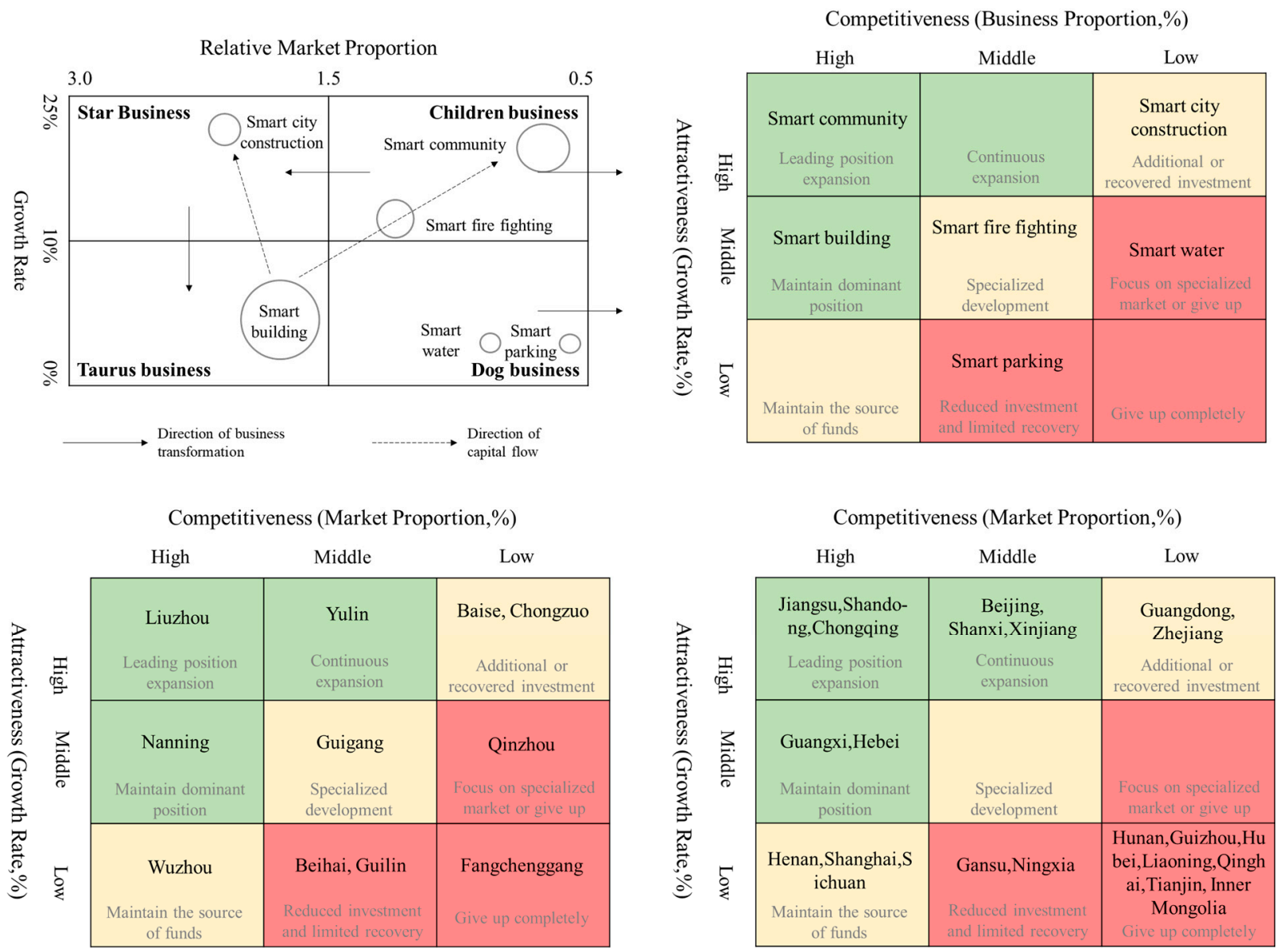

Figure 10. Analysis of important business and market, based on BCG and GE. 
Table 3. The Rotated Component Matrix.

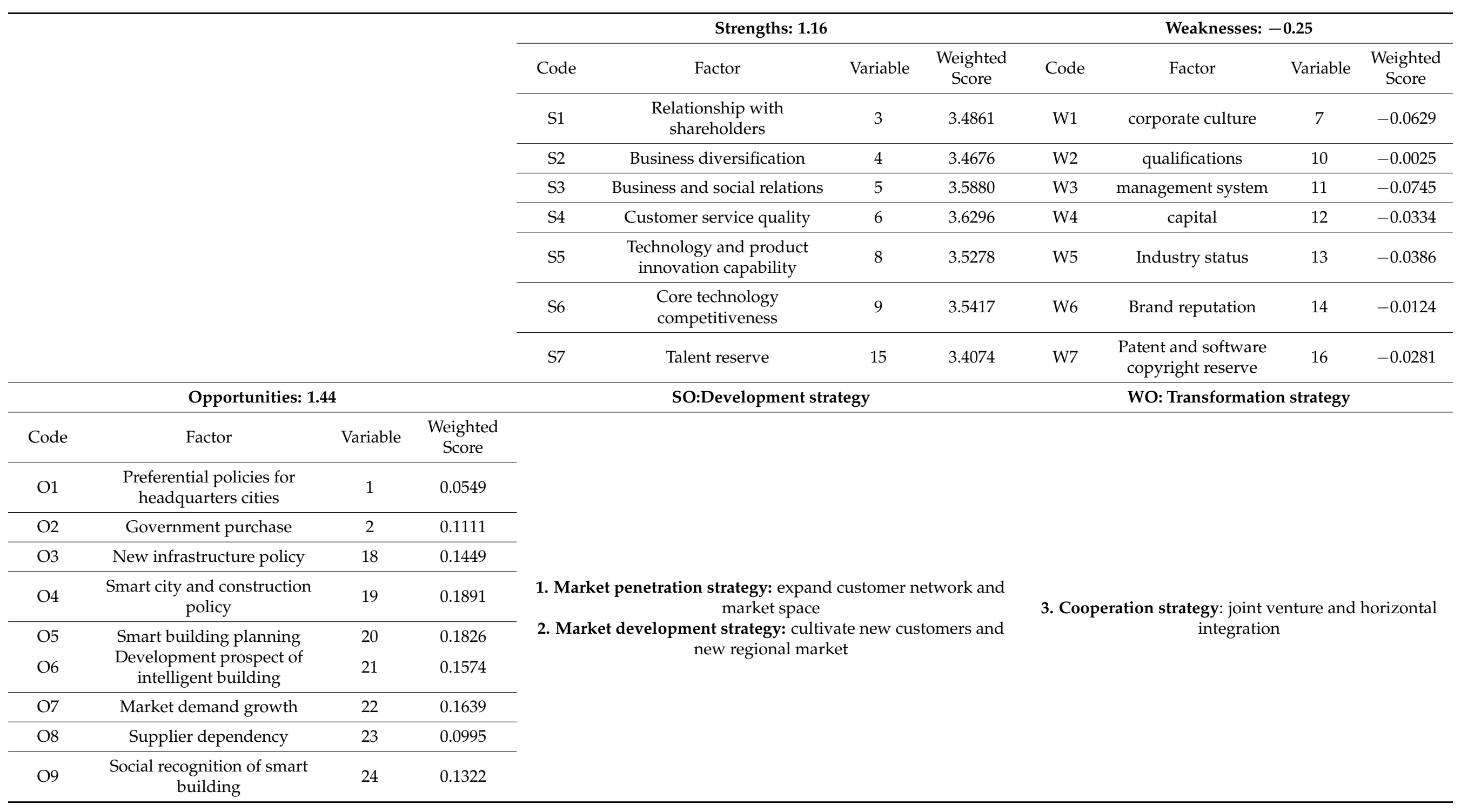


Table 3. Cont.

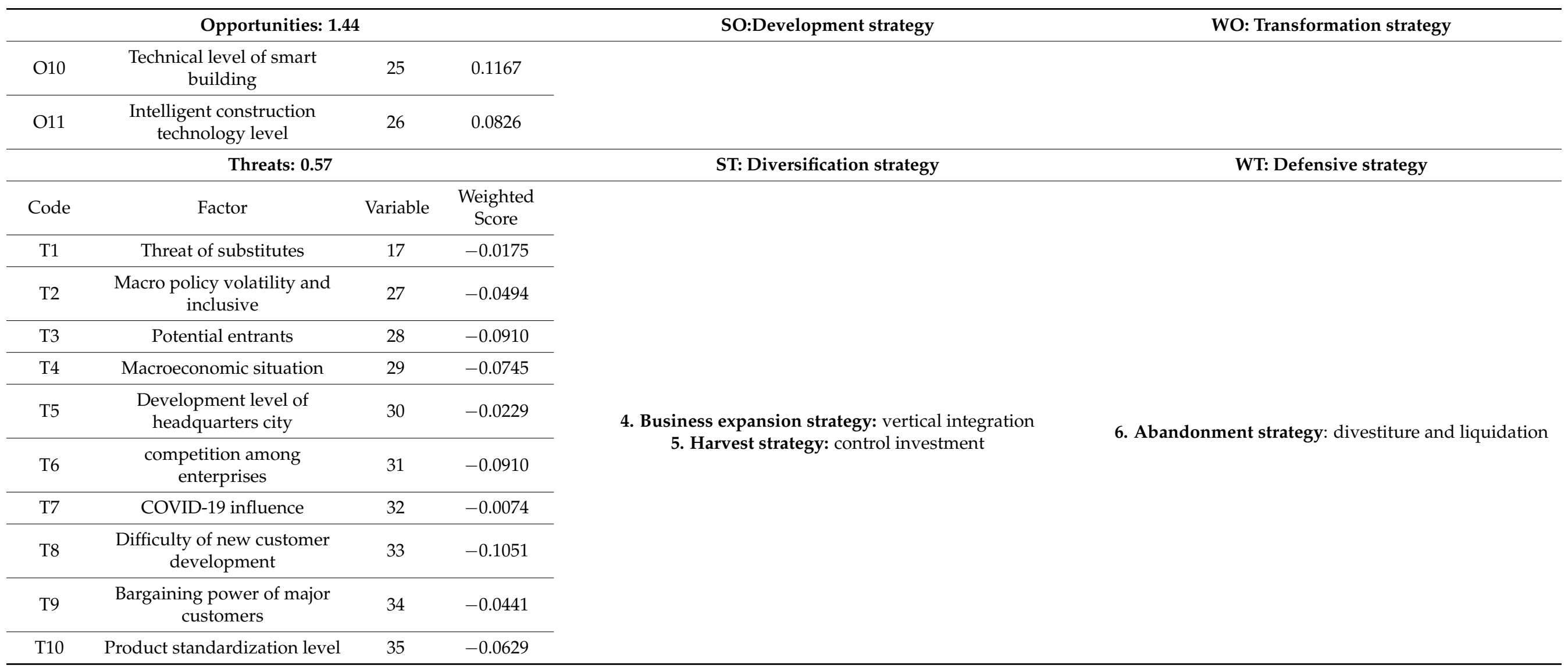




\subsubsection{Best Strategy of Theory}

Based on the data processing and analysis of the questionnaire results, the weighted total scores of strengths, weaknesses, opportunities and threats can be calculated by Equations (1)-(5), and the coordinates of the center of gravity of the strategy quadrilateral can be further worked out to make a strategy quadrilateral (see Figure 11). The center of gravity of the strategy quadrilateral $\mathrm{P}(0.12,0.23)$ is located in the first quadrant, showing that DK's development strengths outweigh its weaknesses and opportunities outweigh its threats, and that the development strategy is the theoretically optimal choice for the company as a whole.

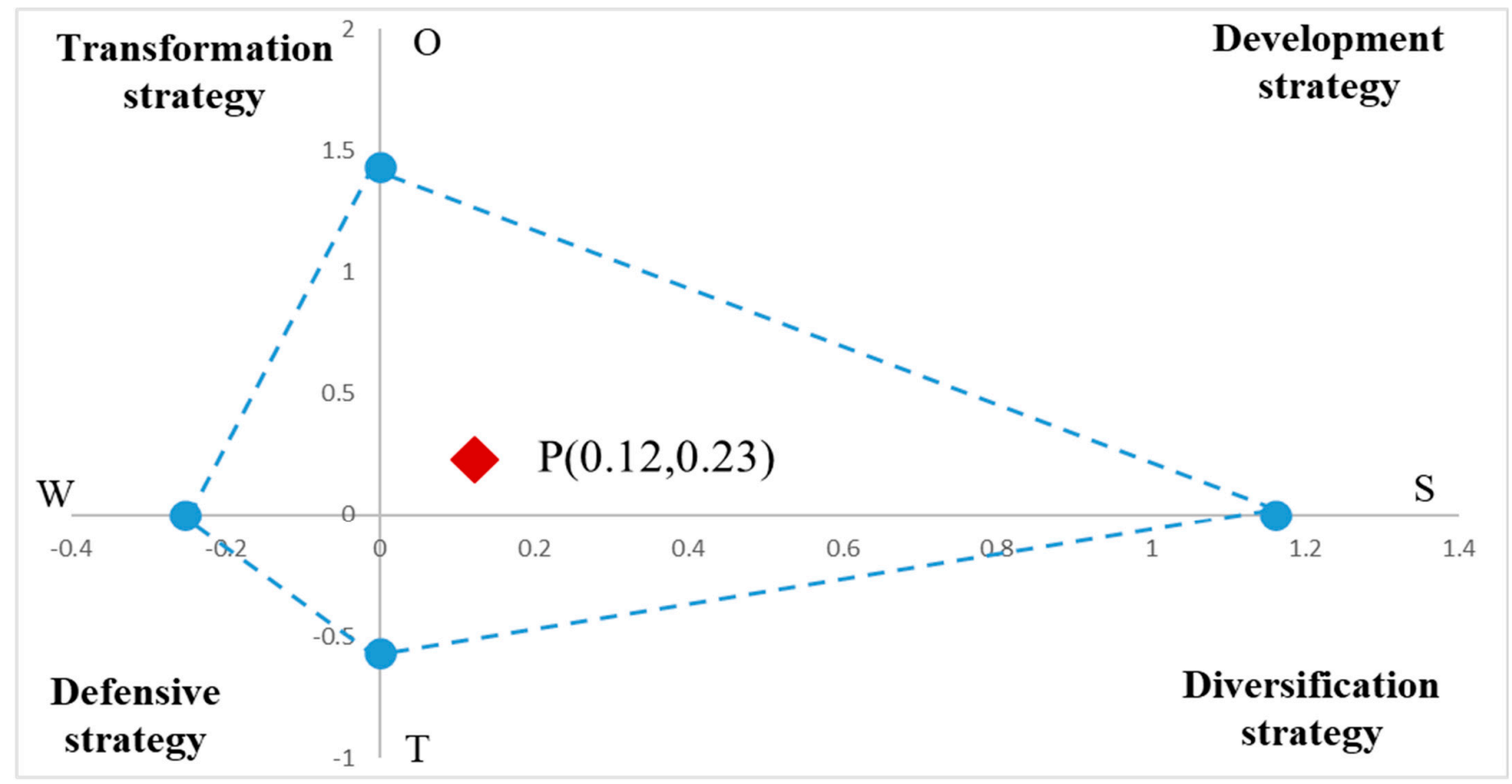

Figure 11. Strategy quadrilateral.

\subsubsection{Best Strategy of Reality}

The six alternative strategy options were analyzed for strategy option matching based on the QSPM matrix [90], and SWOT was adopted to analyze the same variables and weights [91,92]. A total of 13 DK executives, department heads, corresponding managers of shareholder companies, experts in strategic management of corporate development, and representatives of key employees were invited to evaluate the attractiveness scores (ASs) of the six alternative strategy options. The ASs was divided into five grades, expressed by the numbers 1-5. The mode of the scores of 13 participants is taken as the AS. If there is no mode, scoring should be repeated until the mode appears. Opportunity and strength TAS $=$ weighted score $\times$ AS, threat and weakness TAS $=$ weighted score $\times(5$-AS). By summing up TASs, the total attractiveness score of alternative strategy options can be worked out, and a higher score indicates a stronger ability in alternative strategy options to leverage strengths and opportunities to address threats and prevent weaknesses. The calculation results in Table 4 show that the alternative strategy options are ranked as market development strategy (11.06) > business expansion strategy $(10.25)>$ harvest strategy (9.91) > market penetration strategy (9.95) > cooperation strategy (8.11) > abandonment strategy (7.01), thus establishing a priority set of alternative strategy options that can be used to guide the formulation of DK's strategic planning and the establishment of its sustainable development. 
Table 4. Analysis of alternative strategy options based on QSPM.

\begin{tabular}{|c|c|c|c|c|c|c|c|c|c|c|c|c|c|c|c|c|c|c|}
\hline \multirow[t]{2}{*}{ SWOT } & \multirow[t]{2}{*}{ Factor } & \multirow[t]{2}{*}{ Code } & \multirow[t]{2}{*}{ Variable } & \multirow{2}{*}{$\begin{array}{l}\text { Weighted } \\
\text { SCORE }\end{array}$} & \multirow[t]{2}{*}{ Score } & \multirow{2}{*}{$\begin{array}{l}\text { Weighted } \\
\text { Score }\end{array}$} & \multicolumn{2}{|c|}{$\begin{array}{c}\text { Market } \\
\text { Penetration }\end{array}$} & \multicolumn{2}{|c|}{$\begin{array}{l}\text { Market De- } \\
\text { velopment }\end{array}$} & \multicolumn{2}{|c|}{$\begin{array}{l}\text { Cooperation } \\
\text { Strategy }\end{array}$} & \multicolumn{2}{|c|}{$\begin{array}{l}\text { Business } \\
\text { Expansion }\end{array}$} & \multicolumn{2}{|c|}{$\begin{array}{l}\text { Harvest } \\
\text { Strategy }\end{array}$} & \multicolumn{2}{|c|}{$\begin{array}{c}\text { Abandonment } \\
\text { Strategy }\end{array}$} \\
\hline & & & & & & & AS & TAS & AS & TAS & AS & TAS & AS & TAS & AS & TAS & AS & TAS \\
\hline \multirow{6}{*}{ Strengths } & $\begin{array}{l}\text { Relationship with } \\
\text { shareholders }\end{array}$ & S1 & 3 & 0.0433 & 3.49 & 0.1508 & 5 & 0.7542 & 4 & 0.6034 & 4 & 0.6034 & 4 & 0.6034 & 5 & 0.7542 & 2 & 0.3017 \\
\hline & Business diversification & S2 & 4 & 0.0400 & 3.47 & 0.1387 & 4 & 0.5548 & 5 & 0.6935 & 2 & 0.2774 & 5 & 0.6935 & 5 & 0.6935 & 2 & 0.2774 \\
\hline & Business and social relations & S3 & 5 & 0.0547 & 3.59 & 0.1962 & 5 & 0.9811 & 2 & 0.3925 & 3 & 0.5887 & 3 & 0.5887 & 5 & 0.9811 & 1 & 0.1962 \\
\hline & $\begin{array}{l}\text { Technology and product } \\
\text { innovation capability }\end{array}$ & S5 & 8 & 0.0482 & 3.53 & 0.1699 & 3 & 0.5097 & 5 & 0.8495 & 1 & 0.1699 & 5 & 0.8495 & 2 & 0.3398 & 2 & 0.3398 \\
\hline & $\begin{array}{l}\text { Core technology } \\
\text { competitiveness }\end{array}$ & S6 & 9 & 0.0498 & 3.54 & 0.1764 & 4 & 0.7055 & 4 & 0.7055 & 1 & 0.1764 & 4 & 0.7055 & 1 & 0.1764 & 2 & 0.3528 \\
\hline & Talent reserve & S7 & 15 & 0.0367 & 3.41 & 0.1252 & 2 & 0.2503 & 3 & 0.3755 & 2 & 0.2503 & 3 & 0.3755 & 3 & 0.3755 & 3 & 0.3755 \\
\hline \multirow{6}{*}{ Weaknesses } & corporate culture & W1 & 7 & 0.0196 & 3.21 & -0.0629 & 1 & -0.2514 & 3 & -0.1257 & 3 & -0.1257 & 2 & -0.1886 & 3 & -0.1257 & 4 & -0.0629 \\
\hline & qualifications & W2 & 10 & 0.0008 & 3.00 & -0.0025 & 4 & -0.0025 & 5 & 0.0000 & 3 & -0.0049 & 2 & -0.0074 & 4 & -0.0025 & 3 & -0.0049 \\
\hline & capital & W4 & 12 & 0.0106 & 3.14 & -0.0334 & 3 & -0.0667 & 3 & -0.0667 & 5 & 0.0000 & 4 & -0.0334 & 4 & -0.0334 & 1 & -0.1334 \\
\hline & Industry status & W5 & 13 & 0.0122 & 3.16 & -0.0386 & 2 & -0.1159 & 4 & -0.0386 & 3 & -0.0773 & 2 & -0.1159 & 4 & -0.0386 & 3 & -0.0773 \\
\hline & Brand reputation & W6 & 14 & 0.0041 & 3.05 & -0.0124 & 4 & -0.0124 & 4 & -0.0124 & 2 & -0.0373 & 3 & -0.0249 & 4 & -0.0124 & 3 & -0.0249 \\
\hline & $\begin{array}{l}\text { Patent and software } \\
\text { copyright reserve }\end{array}$ & W7 & 16 & 0.0090 & 3.13 & -0.0281 & 2 & -0.0843 & 2 & -0.0843 & 2 & -0.0843 & 2 & -0.0843 & 3 & -0.0562 & 4 & -0.0281 \\
\hline \multirow{5}{*}{ Opportunities } & $\begin{array}{l}\text { Preferential policies for } \\
\text { headquarters cities }\end{array}$ & $\mathrm{O} 1$ & 1 & 0.0171 & 3.20 & 0.0549 & 2 & 0.1098 & 5 & 0.2746 & 4 & 0.2196 & 4 & 0.2196 & 4 & 0.2196 & 3 & 0.1647 \\
\hline & Government purchase & $\mathrm{O} 2$ & 2 & 0.0335 & 3.32 & 0.1111 & 2 & 0.2222 & 5 & 0.5555 & 4 & 0.4444 & 4 & 0.4444 & 3 & 0.3333 & 2 & 0.2222 \\
\hline & New infrastructure policy & $\mathrm{O} 3$ & 18 & 0.0416 & 3.48 & 0.1449 & 4 & 0.5797 & 5 & 0.7247 & 5 & 0.7247 & 5 & 0.7247 & 4 & 0.5797 & 4 & 0.5797 \\
\hline & $\begin{array}{l}\text { Smart city and construction } \\
\text { policy }\end{array}$ & $\mathrm{O} 4$ & 19 & 0.0531 & 3.56 & 0.1891 & 5 & 0.9457 & 5 & 0.9457 & 4 & 0.7566 & 4 & 0.7566 & 4 & 0.7566 & 3 & 0.5674 \\
\hline & Smart building planning & O5 & 20 & 0.0514 & 3.55 & 0.1826 & 3 & 0.5479 & 5 & 0.9131 & 4 & 0.7305 & 4 & 0.7305 & 3 & 0.5479 & 2 & 0.3652 \\
\hline
\end{tabular}


Table 4. Cont.

\begin{tabular}{|c|c|c|c|c|c|c|c|c|c|c|c|c|c|c|c|c|c|c|}
\hline \multirow[t]{2}{*}{ SWOT } & \multirow[t]{2}{*}{ Factor } & \multirow[t]{2}{*}{ Code } & \multirow[t]{2}{*}{ Variable } & \multirow{2}{*}{$\begin{array}{l}\text { Weighted } \\
\text { SCORE }\end{array}$} & \multirow[t]{2}{*}{ Score } & \multirow{2}{*}{$\begin{array}{l}\text { Weighted } \\
\text { Score }\end{array}$} & \multicolumn{2}{|c|}{$\begin{array}{c}\text { Market } \\
\text { Penetration }\end{array}$} & \multicolumn{2}{|c|}{$\begin{array}{l}\text { Market De- } \\
\text { velopment }\end{array}$} & \multicolumn{2}{|c|}{$\begin{array}{l}\text { Cooperation } \\
\text { Strategy }\end{array}$} & \multicolumn{2}{|c|}{$\begin{array}{l}\text { Business } \\
\text { Expansion }\end{array}$} & \multicolumn{2}{|c|}{$\begin{array}{l}\text { Harvest } \\
\text { Strategy }\end{array}$} & \multicolumn{2}{|c|}{$\begin{array}{l}\text { Abandonment } \\
\text { Strategy }\end{array}$} \\
\hline & & & & & & & AS & TAS & AS & TAS & AS & TAS & AS & TAS & AS & TAS & AS & TAS \\
\hline & $\begin{array}{l}\text { Development prospect of } \\
\text { intelligent building }\end{array}$ & O6 & 21 & 0.0449 & 3.50 & 0.1574 & 4 & 0.6294 & 4 & 0.6294 & 4 & 0.6294 & 5 & 0.7868 & 4 & 0.6294 & 3 & 0.4721 \\
\hline & Market demand growth & $\mathrm{O} 7$ & 22 & 0.0465 & 3.52 & 0.1639 & 5 & 0.8197 & 5 & 0.8197 & 4 & 0.6557 & 5 & 0.8197 & 4 & 0.6557 & 3 & 0.4918 \\
\hline & Supplier dependency & O8 & 23 & 0.0302 & 3.30 & 0.0995 & 3 & 0.2986 & 3 & 0.2986 & 1 & 0.0995 & 3 & 0.2986 & 2 & 0.1991 & 1 & 0.0995 \\
\hline & $\begin{array}{l}\text { Social recognition of smart } \\
\text { building }\end{array}$ & O9 & 24 & 0.0384 & 3.44 & 0.1322 & 3 & 0.3965 & 4 & 0.5287 & 3 & 0.3965 & 4 & 0.5287 & 3 & 0.3965 & 3 & 0.3965 \\
\hline & $\begin{array}{c}\text { Technical level of smart } \\
\text { building }\end{array}$ & $\mathrm{O} 10$ & 25 & 0.0351 & 3.32 & 0.1167 & 1 & 0.1167 & 3 & 0.3500 & 1 & 0.1167 & 2 & 0.2334 & 2 & 0.2334 & 2 & 0.2334 \\
\hline & $\begin{array}{l}\text { Intelligent construction } \\
\text { technology level }\end{array}$ & $\mathrm{O} 11$ & 26 & 0.0253 & 3.26 & 0.0826 & 1 & 0.0826 & 2 & 0.1652 & 3 & 0.2478 & 2 & 0.1652 & 2 & 0.1652 & 2 & 0.1652 \\
\hline \multirow{11}{*}{ Threats } & Threat of substitutes & $\mathrm{T} 1$ & 17 & 0.0057 & 3.07 & 0.0175 & 3 & 0.0351 & 4 & 0.0175 & 3 & 0.0351 & 3 & 0.0351 & 1 & 0.0701 & 4 & 0.0175 \\
\hline & $\begin{array}{l}\text { Macro policy volatility and } \\
\text { inclusive }\end{array}$ & $\mathrm{T} 2$ & 27 & 0.0155 & 3.19 & 0.0494 & 2 & 0.1482 & 4 & 0.0494 & 3 & 0.0988 & 4 & 0.0494 & 2 & 0.1482 & 3 & 0.0988 \\
\hline & Potential entrants & T3 & 28 & 0.0278 & 3.28 & 0.0910 & 4 & 0.0910 & 3 & 0.1820 & 4 & 0.0910 & 4 & 0.0910 & 2 & 0.2730 & 4 & 0.0910 \\
\hline & Macroeconomic situation & $\mathrm{T} 4$ & 29 & 0.0229 & 3.26 & 0.0745 & 3 & 0.1490 & 5 & 0.0000 & 3 & 0.1490 & 4 & 0.0745 & 5 & 0.0000 & 2 & 0.2235 \\
\hline & $\begin{array}{l}\text { Development level of } \\
\text { headquarters city }\end{array}$ & T5 & 30 & 0.0074 & 3.12 & 0.0229 & 3 & 0.0458 & 2 & 0.0687 & 4 & 0.0229 & 4 & 0.0229 & 4 & 0.0229 & 2 & 0.0687 \\
\hline & $\begin{array}{c}\text { competition among } \\
\text { enterprises }\end{array}$ & T6 & 31 & 0.0278 & 3.28 & 0.0910 & 4 & 0.0910 & 4 & 0.0910 & 3 & 0.1820 & 4 & 0.0910 & 3 & 0.1820 & 4 & 0.0910 \\
\hline & COVID-19 influence & $\mathrm{T} 7$ & 32 & 0.0025 & 3.02 & 0.0074 & 2 & 0.0222 & 4 & 0.0074 & 5 & 0.0000 & 3 & 0.0148 & 4 & 0.0074 & 3 & 0.0148 \\
\hline & $\begin{array}{c}\text { Difficulty of new customer } \\
\text { development }\end{array}$ & $\mathrm{T} 8$ & 33 & 0.0318 & 3.30 & 0.1051 & 2 & 0.3153 & 4 & 0.1051 & 4 & 0.1051 & 4 & 0.1051 & 1 & 0.4204 & 2 & 0.3153 \\
\hline & $\begin{array}{l}\text { Bargaining power of major } \\
\text { customers }\end{array}$ & T9 & 34 & 0.0139 & 3.18 & 0.0441 & 3 & 0.0883 & 4 & 0.0441 & 2 & 0.1324 & 4 & 0.0441 & 3 & 0.0883 & 3 & 0.0883 \\
\hline & Product standardization level & $\mathrm{T} 10$ & 35 & 0.0196 & 3.21 & 0.0629 & 1 & 0.2514 & 3 & 0.1257 & 5 & 0.0000 & 4 & 0.0629 & 2 & 0.1886 & 2 & 0.1886 \\
\hline & Total & & & 1 & & & & 9.9519 & & 11.0615 & & 8.1132 & & 10.2548 & & 9.9123 & & 7.0061 \\
\hline
\end{tabular}




\section{Discussion}

\subsection{Impact Factors}

From the perspective of factor influence, there was a significant difference between principal component factors, ranked as Factor $1>$ Factor $2>$ Factor $3>$ Factor $4>$ Factor $6>$ Factor 5. The mean common degree of the principal component factors was 3.398. Factor 1 and Factor 2 were both beyond the mean and more than double Factor 5 (minimum). The coefficient of variation of the six principal component factors was $42 \%$, greater than $36 \%$, indicating it had a high degree of heterogeneity [93]. From the connotation of factors, the sustainable development of smart construction enterprises in China resulted from the comprehensive effect of external environment and internal conditions, and the external influence was greater than the internal driving force at the present stage. The total common degree of the external variable reached up to 12.077, much higher than 8.316 of the internal variables.

The mean value of the external variable common degree was 0.575 , and $62 \%$ of the variables had an influence above the mean value. There are five most important influencing variables, ranked as smart building development planning $>$ smart city and smart building policy $>$ smart building development prospect $>$ enterprise competition intensity $>$ smart building technology development level. The national economic development stage and situation, the smart building process and product innovation capacity, as well as the impact of COVID-19 should not be ignored. It proves Adam Smith's [94] findings that the benefits of division of labor and economies of scale are indeed important inducements for enterprise growth. The enterprise density and its competition intensity constrain the enterprise development, consistent with the results of Porter [95] and Hannan [96]. External environmental changes are closely related to the sustainable development of smart construction enterprises, however, in contrast to the views of $\mathrm{Wu}$ and Leo, the policy and the planning environment may play a more significant role, due to Chinese characteristics, at the stages of system construction and development [97]. It is worth noting that potential entrants and supplier dependence have little influence on the development of smart construction enterprises. The new infrastructure policy has not yet shown sufficient efficacy due to its short period of implementation.

The mean value of the internal variable common degree was 0.594 , and $57 \%$ of the variables had an influence above the mean value. There are four most important influencing variables, ranked as: characteristic technology and product $>$ technology and product innovation capability $>$ customer service quality $>$ talent reserve. The influence of the enterprise's position in the industry, capital adequacy and brand reputation should not be ignored. It is worth noting that, affected by qualification, enterprise reform, EPC mode promotion and other factors, the influence of qualification and culture on the development of smart construction enterprises is not so great as expected; the unsatisfactory conversion and application of patents and software copyrights as well as the insufficient efforts to explore the relationship with shareholder companies lead to their not yet being converted into real development benefits. This paper is in general agreement with the findings of Penrose [98] and Nelson et al. [99], that corporate resource allocation and protection, capability development and enhancement are key factors in the growth of smart construction enterprise; however, it differs from the viewpoints of Madani [6], Ghansah [7], and Prahalad [100] in that factors such as technical knowledge, corporate culture, and qualification systems have not fully played their roles in the development and evolution mechanism of enterprises. This phenomenon may be influenced by the development stage of enterprises, and is also closely related to the fact that China is promoting the reform of the management system of the smart building and smart construction industry.

\subsection{Coping Strategies}

The SWOT model can be used to evaluate the factors influencing the sustainable development of smart construction enterprises and guide the formulation and implementation of enterprise development strategies and industry management policies. However, 
the SWOT analysis results are coarse-grained when used alone, and there may usually be a certain degree of deviation between theory and practice. Therefore, whether the decision makers of the enterprise will adopt the analysis results in the end still needs in-depth study based on alternative strategy matching analysis [77,101-103], main business dynamics analysis [62], and the introduction of more analytical methods. Some studies have explored this point to some extent, including the introduction of analytical hierarchy process [40,41], fuzzy evaluation [49-60], gray correlation [47,69], multiple criteria decision-making (MCDM) [48-104], critical success factors (CSFs) [65], Porter ‘s diamond model [105], value-rarity-imitability-organization (VRIO) [106-108], and other methods for a more integrated study. In contrast to the existing studies, this paper introduces strategic evaluation and matching analysis tools such as BCG, GE, and QSPM, and integrates them with SWOT to bring the experience and knowledge of enterprise managers and experts into the final strategic decision analysis process, to put forward a more accurate and reliable alternative strategy priority set with strong feasibility and operability.

The empirical study of DK shows that using the SWOT model to draw a strategy quadrilateral and to calculate the center of gravity coordinates makes it possible to analyze the overall strategy for the development of the company. However, for the development strategy choice of comprehensive enterprises, the overall strategy must be further subdivided. In this paper, the development strategy of DK is summarized into six possible options, and they are quantitatively and comprehensively evaluated and analyzed based on the tools of BCG, GE, and QSPM. The results of the strategy option matching analysis show that the theoretically optimal refinement of the overall strategy is not always the optimal solution for enterprises in practice. For example, business expansion strategy and harvest strategy, ranked second, are both ST strategies rather than SO strategies, and the market penetration strategy, a refinement of SO strategy, is ranked fourth.

The development strategy plays an important guiding role in the sustainable development of enterprises, and it has become a consensus-to-consensus strategic planning and management into their framework of sustainable development. DK has limited development resources. According to the analysis of the external environment and internal conditions, DK should integrate the proposed strategies in Table 5 into the enterprise development strategy formulation and implementation, so as to make the development strategy a source of power for sustainable development and further enhance the comprehensive competitiveness and sustainable development capability of DK. Of course, DK should conduct in-depth analysis based on more detailed information and data to refine and deepen the proposed strategy in order to better fit the development of DK when making its sustainable development strategic plan.

Table 5. Analysis on suggestion strategies of DK company.

\begin{tabular}{|c|c|c|}
\hline Coping Strategies & Business Type & Market Space \\
\hline Market development strategy & $\begin{array}{l}\text { Smart City Construction and Smart } \\
\text { Building }\end{array}$ & $\begin{array}{l}\text { Cities: Hezhou, Hechi, Chongzuo } \\
\text { Provinces: Yunnan, Jiangxi, }\end{array}$ \\
\hline Business expansion strategy & Smart Building and Smart Community & \\
\hline Harvest strategy & Smart Building & $\begin{array}{c}\text { Cities: Wu zhou, Guigang } \\
\text { Provinces: Henan, Shanghai, Sichuan } \\
\text { Cities: Liu zhou, Nan ning, Yu lin }\end{array}$ \\
\hline Market penetration strategy & Smart City Construction & $\begin{array}{c}\text { Provinces: Jiang su, Shan dong, Chong qing, He } \\
\text { bei, Bei jing }\end{array}$ \\
\hline Cooperation strategy & $\begin{array}{c}\text { Smart Community and Smart Fire } \\
\text { Fighting }\end{array}$ & $\begin{array}{l}\text { Cities: Qinzhou, Bai se, Chong zuo } \\
\text { Provinces: Anhui, Fujian }\end{array}$ \\
\hline Abandonment strategy & Smart Parking and Smart Water & $\begin{array}{c}\text { Cities: Beihai, Guilin, Fangchenggang } \\
\text { Provinces: Ningxia, Qinghai, Sichuan, Liaoning, } \\
\text { Inner Mongolia }\end{array}$ \\
\hline
\end{tabular}

A comparative analysis of the similarities and differences between theoretical and practical optimal strategies shows that the integrated use of multiple strategic tools can 
better find the best combination point of theory and practice and help prevent empirical and fuzzy decisions. Overall, the integrated and cross use of strategy analysis tools such as SWOR, BCG, GE, and QSPM based on the questionnaire and interview research data, as well as statistical data from the smart building industry and DK, together with the use of principal component analysis to combine qualitative and quantitative methods, has provided a systematic analytical framework for the assessment of key factors of sustainable development and strategy selection for smart construction enterprises, and also provided a rigorous scientific basis for strategic decision-making and implementation, with great theoretical value and practical significance.

\section{Conclusions}

Smart construction enterprises are the key subjects in maintaining the health of the smart building industry. Against the backdrop of the new round of technology and industrial revolution, the sustainable development and strategic management of enterprises are facing unprecedented challenges. Based on SWOT, BCG, GE, QSPM and principal component analysis methods, this paper refines the elements influencing the sustainable development of smart construction enterprises in China into 28 variables and six key factors, and further proposes a strategy priority set consisting of six alternative strategy options. In terms of the influence of comprehensive factors, there is a significant difference in influence between key factors, and the external force is far greater than the internal driving force. From the perspective of strategic decision-making and implementation, with the rapid changes in the economic situation and market environment in recent years, as well as increasing uncertainty factors and their growing influence, it is not enough for smart construction enterprises to mainly rely on external forces to promote development, rather, they should improve the endogenous driving force as early as possible. From the perspective of enterprise development stage, smart construction enterprises in China have completed the preliminary accumulation of funds, capital, talents, technology and market for development, and most of them have entered the period of rapid growth. Therefore, it is urgent that they develop and implement the enterprise development strategy planning, and analyze and define the core objectives and major tasks of enterprise development, so as to continuously enhance the comprehensive competitiveness for sustainable development of enterprises based on efficient and full use of the limited human, financial and material resources and external opportunities, with the help of the development strategy. Smart construction enterprises in China, therefore, in order to achieve sustainable development, must strive to improve resource conditions and enhance the comprehensive strength in terms of technology, quality, capital, talent, culture, integrity and brand, accurately grasp the positioning and direction of the development, formulate and implement scientific and reasonable development strategic planning, leverage the external environment to pry and activate the endogenous driving force, and form a new pattern of differentiated sustainable development.

It is worth noting that this paper does not apply to all Chinese companies; its findings are applicable to smart construction enterprises at a similar development level and stage to DK. These enterprises should be small and medium-sized private companies, mainly engaged in general contracting for smart construction and building industrialization, with competitive advantages at regional or even national level in specific areas, and able to achieve sustainable development based on the full utilization of their own resources and external opportunities. Some of the findings in its case studies are also of value to similar enterprises in other countries around the world, such as those on guiding rapid growth by virtue of industrial development policies and industry development plans, and those on creating local brand dependence by improving the customer service quality.

The combined use of SWOR, BCG, GE, QSPM and other strategy analysis tools and principal component analysis methods in this paper is innovative to a certain extent. However, it also has some shortcomings due to many limitations. For example, only DK was empirically studied in this paper. More cases are needed in the future for comparative 
studies to gain more experience about the sustainability of smart construction companies. In addition, there are still some subjective and experiential factors in the framework provided in this paper. Due to the lack of support by more elastic and dynamic data, the optimal option can only be selected from the existing statically analyzed alternatives, which can hardly cope with the increasing influence of uncertainty and contingency factors. Overall, the research framework constructed in this paper can still be further improved according to the aforementioned deficiencies, so as to improve the scientificity, rationality, accuracy and practicality of the research findings. To carry out comparative empirical research based on more cases and dynamic data, and to appropriately incorporate uncertainty and accidental factors into the research framework will be new directions for our next research efforts in the future.

Author Contributions: Conceptualization, S.Z. and P.Z.; methodology, S.Z.; software, S.Z. and W.L.; validation, S.Z.; formal analysis, S.Z.; investigation, S.Z., W.L. and P.Z.; resources, P.Z.; data curation, S.Z. and W.L.; writing—original draft preparation, S.Z. and W.L.; writing—review and editing, P.Z.; visualization, S.Z.; supervision, P.Z.; project administration, P.Z.; funding acquisition, P.Z. All authors have read and agreed to the published version of the manuscript.

Funding: This paper and the related research are financially supported by the National Natural Science Foundation of China (Project Number: 51,768,029).

Data Availability Statement: The data used in this paper mainly come from the questionnaire investigation, annual statistical report of DK company, and China Statistical Yearbook published national bureau of statistics. Most of the data can be obtained by visiting the following links: http:/ /www.stats.gov.cn/tjsj/ndsj/ (accessed on 13 February 2021).

Conflicts of Interest: The authors declare no conflict of interest.

Appendix A

Table A1. Internal condition-oriented DK questionnaire design.

\begin{tabular}{|c|c|c|c|}
\hline & & Strength (S) & Weakness (W) \\
\hline \multirow{5}{*}{ Resource } & Qualification & & $\begin{array}{l}\text { 10. How detrimental DK's qualifications is to the } \\
\text { construction of its competitive advantage }\end{array}$ \\
\hline & $\begin{array}{l}\text { Human } \\
\text { resources }\end{array}$ & $\begin{array}{l}\text { 15. How detrimental DK's insufficient } \\
\text { talent pool is to the construction of its } \\
\text { competitive advantage }\end{array}$ & \\
\hline & Brand & $\begin{array}{l}\text { 5. How beneficial DK's social and business } \\
\text { relationships are to the construction of its } \\
\text { competitive advantage }\end{array}$ & $\begin{array}{l}\text { 13. How detrimental DK's industry position is to the } \\
\text { construction of its competitive advantage } \\
\text { 14. How detrimental DK's brand reputation is to the } \\
\text { construction of its competitive advantage }\end{array}$ \\
\hline & Technology & $\begin{array}{l}\text { 9. How beneficial DK's core technologies } \\
\text { are the construction of its competitive } \\
\text { advantage }\end{array}$ & $\begin{array}{l}\text { 16. How detrimental DK's weak reserves of patents } \\
\text { and software copyrights are to the construction of its } \\
\text { competitive advantage }\end{array}$ \\
\hline & Finance & & $\begin{array}{l}\text { 12. How detrimental DK's capital scale is detrimental } \\
\text { to the construction of its competitive advantage }\end{array}$ \\
\hline \multirow[t]{4}{*}{ Capabilities } & Marketing & $\begin{array}{l}\text { 4. How beneficial DK's business } \\
\text { diversification is to the construction of its } \\
\text { competitive advantage } \\
\text { 6. How beneficial the customer service } \\
\text { quality of DK is to the construction of its } \\
\text { competitive advantage }\end{array}$ & \\
\hline & $\begin{array}{l}\text { Research } \\
\text { and devel- } \\
\text { opment }\end{array}$ & $\begin{array}{l}\text { 8. How beneficial DK's technological and } \\
\text { product innovation capabilities are to the } \\
\text { construction of its competitive advantage }\end{array}$ & \\
\hline & Organization & $\begin{array}{l}\text { 3. How beneficial } \mathrm{DK}^{\prime} \text { 's relationship with } \\
\text { its parent company is to the construction of } \\
\text { its competitive advantage }\end{array}$ & $\begin{array}{l}\text { 11. How detrimental DK's imperfect management } \\
\text { system is to the construction of its competitive } \\
\text { advantage }\end{array}$ \\
\hline & Culture & & $\begin{array}{l}\text { 7. How detrimental DK's weak cultural attractiveness } \\
\text { is to the construction of its competitive advantage }\end{array}$ \\
\hline
\end{tabular}


Table A2. External environment-oriented DK questionnaire design.

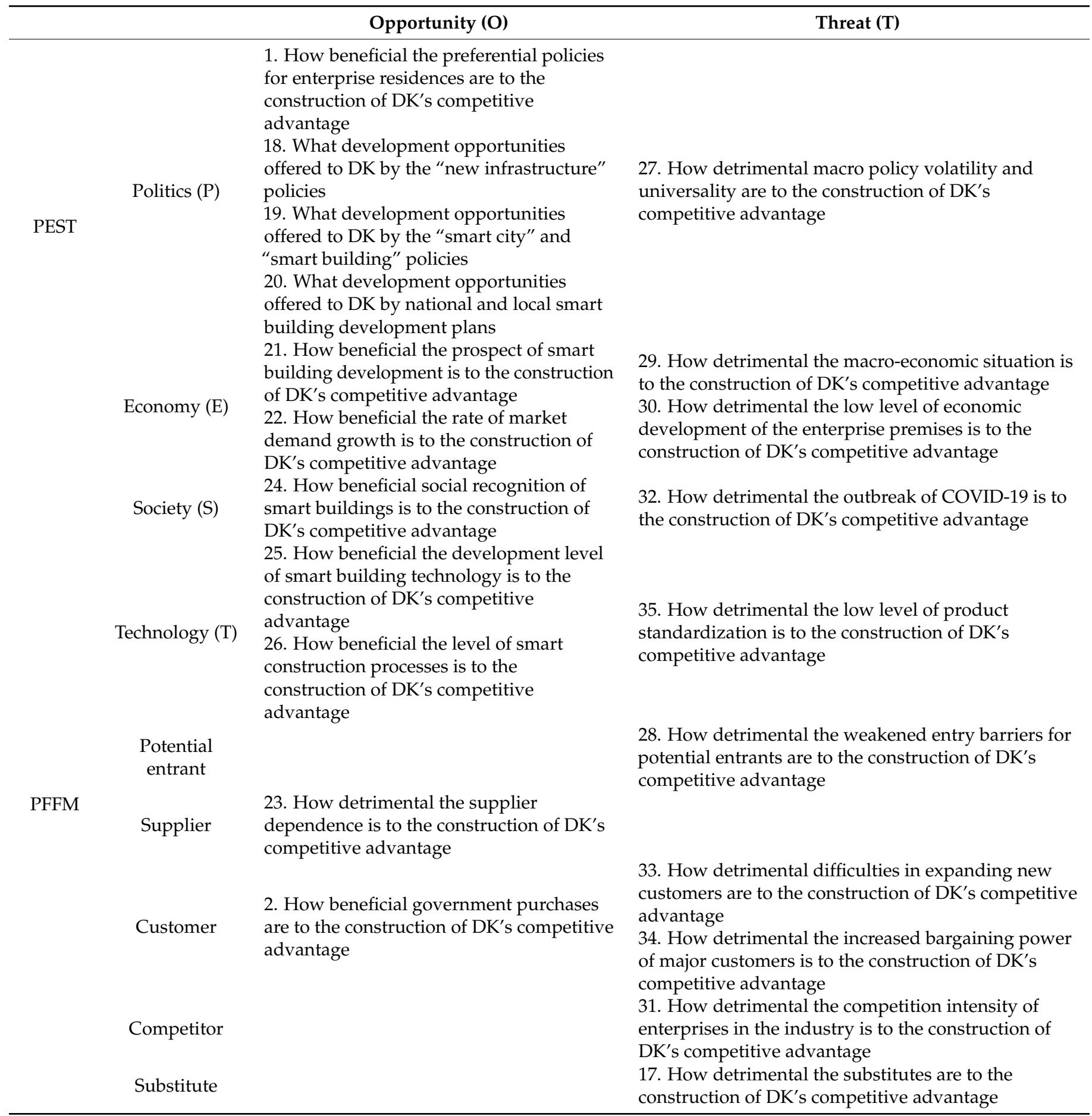


Table A3. Questionnaire score and weight analysis.

\begin{tabular}{|c|c|c|c|c|c|c|c|}
\hline $\begin{array}{ll}\text { Items } & \text { Grade } \\
\end{array}$ & 1 & 2 & 3 & 4 & 5 & Score & Weight \\
\hline 1 & 23 & 39 & 63 & 53 & 38 & 3.20 & 0.0171 \\
\hline 2 & 18 & 36 & 60 & 63 & 39 & 3.32 & 0.0335 \\
\hline 3 & 12 & 44 & 40 & 67 & 53 & 3.49 & 0.0433 \\
\hline 4 & 17 & 28 & 63 & 53 & 55 & 3.47 & 0.0400 \\
\hline 5 & 17 & 21 & 49 & 76 & 53 & 3.59 & 0.0547 \\
\hline 6 & 17 & 25 & 47 & 59 & 68 & 3.63 & 0.0563 \\
\hline 7 & 19 & 49 & 56 & 52 & 40 & 3.21 & 0.0196 \\
\hline 8 & 18 & 31 & 51 & 51 & 65 & 3.53 & 0.0482 \\
\hline 9 & 19 & 34 & 42 & 53 & 68 & 3.54 & 0.0498 \\
\hline 10 & 24 & 53 & 63 & 50 & 26 & 3.00 & 0.0008 \\
\hline 11 & 22 & 33 & 59 & 71 & 31 & 3.26 & 0.0229 \\
\hline 12 & 22 & 47 & 56 & 60 & 31 & 3.14 & 0.0106 \\
\hline 13 & 27 & 28 & 75 & 56 & 30 & 3.16 & 0.0122 \\
\hline 14 & 25 & 45 & 65 & 57 & 24 & 3.05 & 0.0041 \\
\hline 15 & 22 & 35 & 50 & 51 & 58 & 3.41 & 0.0367 \\
\hline 16 & 21 & 49 & 59 & 55 & 32 & 3.13 & 0.0090 \\
\hline 17 & 21 & 53 & 57 & 60 & 25 & 3.07 & 0.0057 \\
\hline 18 & 17 & 29 & 54 & 65 & 51 & 3.48 & 0.0416 \\
\hline 19 & 16 & 33 & 47 & 53 & 67 & 3.56 & 0.0531 \\
\hline 20 & 14 & 33 & 46 & 66 & 57 & 3.55 & 0.0514 \\
\hline 21 & 12 & 35 & 58 & 54 & 57 & 3.50 & 0.0449 \\
\hline 22 & 13 & 31 & 48 & 78 & 46 & 3.52 & 0.0465 \\
\hline 23 & 15 & 38 & 64 & 66 & 33 & 3.30 & 0.0302 \\
\hline 24 & 13 & 36 & 56 & 64 & 47 & 3.44 & 0.0384 \\
\hline 25 & 17 & 35 & 62 & 65 & 37 & 3.32 & 0.0351 \\
\hline 26 & 18 & 36 & 61 & 73 & 28 & 3.26 & 0.0253 \\
\hline 27 & 20 & 33 & 74 & 65 & 24 & 3.19 & 0.0155 \\
\hline 28 & 17 & 29 & 74 & 69 & 27 & 3.28 & 0.0278 \\
\hline 29 & 17 & 33 & 70 & 69 & 27 & 3.26 & 0.0229 \\
\hline 30 & 19 & 47 & 68 & 54 & 28 & 3.12 & 0.0074 \\
\hline 31 & 16 & 40 & 62 & 64 & 34 & 3.28 & 0.0278 \\
\hline 32 & 28 & 45 & 64 & 53 & 26 & 3.02 & 0.0025 \\
\hline 33 & 22 & 32 & 59 & 65 & 38 & 3.30 & 0.0318 \\
\hline 34 & 17 & 39 & 67 & 74 & 19 & 3.18 & 0.0139 \\
\hline 35 & 14 & 45 & 63 & 70 & 24 & 3.21 & 0.0196 \\
\hline
\end{tabular}

\section{References}

1. Stefanic, M.; Stankovski, V. A review of technologies and applications for smart construction. Proc. Inst. Civ. Eng. Civ. Eng. 2019, 172, 83-87. [CrossRef]

2. Nugur, A.; Pipattanasomporn, M.; Kuzlu, M.; Rahman, S. Design and Development of an IoT Gateway for Smart Building Applications. IEEE Internet Things J. 2019, 6, 9020-9029. [CrossRef]

3. Verma, A.; Prakash, S.; Srivastava, V.; Kumar, A.; Mukhopadhyay, S.C. Sensing, Controlling, and IoT Infrastructure in Smart Building: A Review. IEEE Sens. J. 2019, 19, 9036-9046. [CrossRef]

4. Le, D.N.; Le Tuan, L.; Tuan, M.N.D. Smart-building management system: An Internet-of-Things (IoT) application business model in Vietnam. Technol. Forecast. Soc. Chang. 2019, 141, 22-35. [CrossRef]

5. Bashir, M.R.; Gill, A.Q.; Beydoun, G.; McCusker, B. Big Data Management and Analytics Metamodel for IoT-Enabled Smart Buildings. IEEE Access 2020, 8, 169740-169758. [CrossRef]

6. Madani, F.; Daim, T.; Weng, C. 'Smart building' technology network analysis: Applying core-periphery structure analysis. Int. J. Manag. Sci. Eng. Manag. 2015, 12,1-11. [CrossRef]

7. Ghansah, F.A.; Owusu-Manu, D.-G.; Ayarkwa, J.; Edwards, D.J.; Hosseini, M.R. Assessing the level of awareness of smart building technologies (SBTs) in the developing countries. J. Eng. Des. Technol. 2021. [CrossRef]

8. Chew, M.; Teo, E.; Shah, K.; Kumar, V.; Hussein, G. Evaluating the Roadmap of 5G Technology Implementation for Smart Building and Facilities Management in Singapore. Sustainability 2020, 12, 10259. [CrossRef]

9. Xu, Y.; Ahokangas, P.; Turunen, M.; Mäntymäki, M.; Heikkilä, J. Xu Platform-Based Business Models: Insights from an Emerging Ai-Enabled Smart Building Ecosystem. Electronics 2019, 8, 1150. [CrossRef]

10. Sun, Y.; Wang, R.S.; Li, X.M. A Distributed Rule System for Smart Building. Ad Hoc Sens. Wirel. Netw. 2015, $29,1-29$. 
11. Vijayan, D.S.; Rose, A.L.; Arvindan, S.; Revathy, J.; Amuthadevi, C. Automation systems in smart buildings: A review. J. Ambient. Intell. Humaniz. Comput. 2020, 1-13. [CrossRef]

12. Froufe, M.; Chinelli, C.; Guedes, A.; Haddad, A.; Hammad, A.; Soares, C. Smart Buildings: Systems and Drivers. Buildings 2020, 10, 153. [CrossRef]

13. Li, W.; Koo, C.; Cha, S.H.; Lai, J.H.; Lee, J. A conceptual framework for the real-time monitoring and diagnostic system for the optimal operation of smart building: A case study in Hotel ICON of Hong Kong. Energy Procedia 2019, 158, 3107-3112. [CrossRef]

14. Xu, W.; Zhang, J.; Kim, J.Y.; Huang, W.; Kanhere, S.S.; Jha, S.K.; Hu, W. The Design, Implementation, and Deployment of a Smart Lighting System for Smart Buildings. IEEE Internet Things J. 2019, 6, 7266-7281. [CrossRef]

15. Sun, Y.; Wu, T.-Y.; Li, X.; Guizani, M. A Rule Verification System for Smart Buildings. IEEE Trans. Emerg. Top. Comput. 2016, 5, 367-379. [CrossRef]

16. Al Dakheel, J.; Del Pero, C.; Aste, N.; Leonforte, F. Smart buildings features and key performance indicators: A review. Sustain. Cities Soc. 2020, 61, 102328. [CrossRef]

17. Amin, U.; Hossain, M.; Lu, J.; Fernandez, E. Performance analysis of an experimental smart building: Expectations and outcomes. Energy 2017, 135, 740-753. [CrossRef]

18. Cheng, M.-Y.; Chiu, K.-C.; Lien, L.-C.; Wu, Y.-W.; Lin, J.-J. Economic and energy consumption analysis of smart building - MEGA house. Build. Environ. 2016, 100, 215-226. [CrossRef]

19. Behzadi, A.; Arabkoohsar, A.; Yang, Y. Optimization and dynamic techno-economic analysis of a novel PVT-based smart building energy system. Appl. Therm. Eng. 2020, 181, 115926. [CrossRef]

20. Janhunen, E.; Leskinen, N.; Junnila, S. The Economic Viability of a Progressive Smart Building System with Power Storage. Sustainability 2020, 12, 5998. [CrossRef]

21. Lazarova-Molnar, S.; Mohamed, N. Collaborative data analytics for smart buildings: Opportunities and models. Clust. Comput. 2017, 22, 1065-1077. [CrossRef]

22. Bolchini, C.; Geronazzo, A.; Quintarelli, E. Smart buildings: A monitoring and data analysis methodological framework. Build. Environ. 2017, 121, 93-105. [CrossRef]

23. Yang, Z.; Wang, Y.; Sun, C. Emerging Information Technology Acceptance Model for The Development of Smart Construction System. J. Civ. Eng. Manag. 2018, 24, 457-468. [CrossRef]

24. Cauchi, N.; Hoque, K.A.; Stoelinga, M.; Abate, A. Maintenance of Smart Buildings using Fault Trees. ACM Trans. Sens. Netw. 2018, 14, 1-25. [CrossRef]

25. Sepasgozar, S.M.E.; Loosemore, M.; Davis, S.R. Conceptualising information and equipment technology adoption in construction. Eng. Constr. Arch. Manag. 2016, 23, 158-176. [CrossRef]

26. Qi, B.; Razkenari, M.; Li, J.; Costin, A.; Kibert, C.; Qian, S. Investigating U.S. Industry Practitioners' Perspectives towards the Adoption of Emerging Technologies in Industrialized Construction. Buildings 2020, 10, 85. [CrossRef]

27. Sepasgozar, S.M. Digital technology utilisation decisions for facilitating the implementation of Industry 4.0 technologies. Constr Innov. 2020. [CrossRef]

28. Sepasgozar, S.M.E.; Davis, S. Digital Construction Technology and Job-site Equipment Demonstration: Modelling Relationship Strategies for Technology Adoption. Buildings 2019, 9, 158. [CrossRef]

29. Sepasgozar, S.M.E.; Davis, S. Construction Technology Adoption Cube: An Investigation on Process, Factors, Barriers, Drivers and Decision Makers Using NVivo and AHP Analysis. Buildings 2018, 8, 74. [CrossRef]

30. Sepasgozar, S.M.; Davis, S.; Loosemore, M.; Bernold, L. An investigation of modern building equipment technology adoption in the Australian construction industry. Eng. Constr. Arch. Manag. 2018, 25, 1075-1091. [CrossRef]

31. Fauzi, C.; Sulistyo, S. Widyawan A survey of group activity recognition in smart building. In Proceedings of the 2018 International Conference on Signals and Systems (ICSigSys), Bali, Indonesia, 1-3 May 2018; Volume 2018, pp. $13-19$.

32. Santana, J.R.; Sanchez, L.; Sotres, P.; Lanza, J.; Llorente, T.; Munoz, L. A Privacy-Aware Crowd Management System for Smart Cities and Smart Buildings. IEEE Access 2020, 8, 135394-135405. [CrossRef]

33. Apanaviciene, R.; Urbonas, R.; Fokaides, P. Smart Building Integration into a Smart City: Comparative Study of Real Estate Development. Sustainability 2020, 12, 9376. [CrossRef]

34. Sepasgozar, S.M.; Hawken, S.; Sargolzaei, S.; Foroozanfa, M. Implementing citizen centric technology in developing smart cities: A model for predicting the acceptance of urban technologies. Technol. Forecast. Soc. Chang. 2019, 142, 105-116. [CrossRef]

35. Lopez, L.R.; Castro, A.G. Sustainability and Resilience in Smart City Planning: A Review. Sustainability 2020, 13, 181. [CrossRef]

36. Apanaviciene, R.; Vanagas, A.; Fokaides, P.A. Smart Building Integration into a Smart City (SBISC): Development of a New Evaluation Framework. Energies 2020, 13, 2190. [CrossRef]

37. Yoon, C.Y. Measurement of Enterprise Smart Business Performance on a Smart Business Management. IEICE Trans. Inf. Syst. 2021, 104, 56-62. [CrossRef]

38. Sepasgozar, S.; Karimi, R.; Farahzadi, L.; Moezzi, F.; Shirowzhan, S.; Ebrahimzadeh, S.M.; Hui, F.; Aye, L. A Systematic Content Review of Artificial Intelligence and the Internet of Things Applications in Smart Home. Appl. Sci. 2020, 10, 3074. [CrossRef]

39. Slupik, S.; Lorek, P. Sustainable Enterprise by Sustainable Product? A Case of Smart Home Systems. Ekonomia I Srodowisko-Econ. Environ. 2019, 2, 146-159. [CrossRef]

40. Ullah, F.; Sepasgozar, S.M.E.; Wang, C. A Systematic Review of Smart Real Estate Technology: Drivers of, and Barriers to, the Use of Digital Disruptive Technologies and Online Platforms. Sustainability 2018, 10, 3142. [CrossRef] 
41. Kitouni, I.; Benmerzoug, D.; Lezzar, F. Smart Agricultural Enterprise System Based on Integration of Internet of Things and Agent Technology. J. Organ. End User Comput. 2018, 30, 64-82. [CrossRef]

42. Pourzolfaghar, Z.; Bastidas, V.; Helfert, M. Standardisation of enterprise architecture development for smart cities. J. Knowl. Econ. 2020, 11, 1336-1357. [CrossRef]

43. Impedovo, D.; Pirlo, G. Artificial Intelligence Applications to Smart City and Smart Enterprise. Appl. Sci. 2020, 10, 2944. [CrossRef]

44. Maida, J. Global Smart Buildings Market 2020-2024 Report, Technavio Research. 2020. Available online: https://analysis. technavio.com/smart-building-market-forecast-research (accessed on 21 January 2021).

45. Mordor Intelligence. Smart Building Market-Growth, Trends, Covid-19 Impact, and Forecasts (2021-2026), Mordor Intelligence. Available online: https:/ / www.mordorintelligence.com/industry-reports/smart-building-market (accessed on 21 April 2021).

46. Data Bridge Market Research. Global Smart Building Market-Industry Trends and Forecast to 2027, Data Bridge Market Research. Available online: https:/ / www.databridgemarketresearch.com/reports/global-smart-building-market\# (accessed on 21 April 2021).

47. Adeli, A.; Zadsafar, S.; Alishahi, A.R.; Chafi, H.G. A SWOT analysis on Iranian fishmeal industry. Iran. J. Fish. Sci. 2020, 19, 2909-2924. [CrossRef]

48. Lagoudakis, A.; Mckendree, M.G.; Malone, T.; Caputo, V. Incorporating producer opinions into a SWOT analysis of the U.S. tart cherry industry. Int. Food Agribus. Manag. Rev. 2020, 23, 547-561. [CrossRef]

49. Brunnhofer, M.; Gabriella, N.; Schöggl, J.-P.; Stern, T.; Posch, A. The biorefinery transition in the European pulp and paper industry - A three-phase Delphi study including a SWOT-AHP analysis. For. Policy Econ. 2020, 110, 101882. [CrossRef]

50. Jiskani, I.M.; Shah, S.A.A.; Qingxiang, C.; Zhou, W.; Lu, X. A multi-criteria based SWOT analysis of sustainable planning for mining and mineral industry in Pakistan. Arab. J. Geosci. 2020, 13, 1-16. [CrossRef]

51. Khaba, S.; Bhar, C. Quantifying SWOT analysis for the Indian coal mining industry using Fuzzy DEMATEL. Benchmark. Int. J. 2017, 24, 882-902. [CrossRef]

52. Zhü, K.; Zhao, S.-Y.; Yang, S.; Liang, C.; Gu, D. Where is the way for rare earth industry of China: An analysis via ANP-SWOT approach. Resour. Policy 2016, 49, 349-357. [CrossRef]

53. Kim, Y.-J.; Park, J. A Sustainable Development Strategy for the Uzbekistan Textile Industry: The Results of a SWOT-AHP Analysis. Sustainability 2019, 11, 4613. [CrossRef]

54. Kanat, S.; Abbasi, S.A.; Peerzada, M.H.; Atilgan, T. SWOT analysis of Pakistan's textile and clothing industry. Ind. Text. 2018, 69, 502-510.

55. Xu, D.; Dong, L. Strategic diagnosis of China's modern coal-to-chemical industry using an integrated SWOT-MCDM framework. Clean Technol. Environ. Policy 2018, 21, 517-532. [CrossRef]

56. Karimi, M.; Niknamfar, A.H.; Niaki, S.T.A. An application of fuzzy-logic and grey-relational ANP-based SWOT in the ceramic and tile industry. Knowl. Based Syst. 2019, 163, 581-594. [CrossRef]

57. Khan, M.I. Evaluating the strategies of compressed natural gas industry using an integrated SWOT and MCDM approach. J. Clean. Prod. 2018, 172, 1035-1052. [CrossRef]

58. Szum, K.; Nazarko, J. Exploring the Determinants of Industry 4.0 Development Using an Extended SWOT Analysis: A Regional Study. Energies 2020, 13, 5972. [CrossRef]

59. Zhao, J.; Liu, H.; Xue, W. PEST Embedded SWOT Analysis on China's E-Commerce Industry Development Strategy. J. Electron. Commer. Organ. 2019, 17, 55-68. [CrossRef]

60. Zhang, Y.; Yuan, L.; Ye, T. Management Innovation of Marine Cultural Industry Based on SWOT and AHP. J. Coast. Res. 2020, 112, 199-202. [CrossRef]

61. Fan, T.; Xue, D.Q. Sustainable Development of Cultural Industry in Shaanxi Province of Northwest China: A SWOT and AHP Analysis. Sustainability 2018, 10, 2830. [CrossRef]

62. Irfan, M.; Hao, Y.; Panjwani, M.K.; Khan, D.; Chandio, A.A.; Li, H. Competitive assessment of South Asia's wind power industry: SWOT analysis and value chain combined model. Energy Strat. Rev. 2020, 32, 100540. [CrossRef]

63. Wang, X.; Li, C.; Shang, J.; Yang, C.; Zhang, B.; Ke, X. Strategic Choices of China's New Energy Vehicle Industry: An Analysis Based on ANP and SWOT. Energies 2017, 10, 537. [CrossRef]

64. Shinno, H.; Yoshioka, H.; Marpaung, S.; Hachiga, S. Quantitative SWOT analysis on global competitiveness of machine tool industry. J. Eng. Des. 2006, 17, 251-258. [CrossRef]

65. Khalid, H.; Zhang, H.; Liu, C.; Li, W.; Abuzar, M.K.; Amin, F.R.; Liu, G.; Chen, C. PEST (political, environmental, social \& technical) analysis of the development of the waste-to-energy anaerobic digestion industry in China as a representative for developing countries. Sustain. Energy Fuels 2020, 4, 1048-1062. [CrossRef]

66. Zhu, L.; Hiltunen, E.; Antila, E.; Huang, F.; Song, L. Investigation of China's bio-energy industry development modes based on a SWOT-PEST model. Int. J. Sustain. Energy 2014, 34, 552-559. [CrossRef]

67. Moreno-Izquierdo, L.; Ramón-Rodríguez, A.; Perles-Ribes, J. Pricing Strategies of the European Low-Cost Carriers Explained Using Porter's Five Forces Model. Tour. Econ. 2016, 22, 293-310. [CrossRef]

68. Yunna, W.; Yisheng, Y. The competition situation analysis of shale gas industry in China: Applying Porter's five forces and scenario model. Renew. Sustain. Energy Rev. 2014, 40, 798-805. [CrossRef] 
69. Hopkins, H. Applying Michael Porter's extended rivalry model to the robotics industry. Ind. Robot. Int. J. 2008, 35, 397-399. [CrossRef]

70. Mutandwa, E.; Kanuma, N.T.; Rusatira, E.; Kwiringirimana, T.; Mugenzi, P.; Govere, I.; Foti, R. Analysis of coffee export marketing in Rwanda: Application of the Boston consulting group matrix. Afr. J. Bus. Manag. 2009, 3, 210-219.

71. Myllylä, Y.; Kaivo-Oja, J. Integrating Delphi methodology to some classical concepts of the Boston consulting group framework: Arctic maritime technology BCG Delphi foresight-A pilot study from Finland. Eur. J. Future Res. 2015, 3. [CrossRef]

72. Sepasgozar, S.; Hui, F.; Shirowzhan, S.; Foroozanfar, M.; Yang, L.; Aye, L. Lean Practices Using Building Information Modeling (BIM) and Digital Twinning for Sustainable Construction. Sustainability 2020, 13, 161. [CrossRef]

73. Shirowzhan, S.; Sepasgozar, S.M.; Edwards, D.J.; Li, H.; Wang, C. BIM compatibility and its differentiation with interoperability challenges as an innovation factor. Autom. Constr. 2020, 112, 103086. [CrossRef]

74. Zima, K.; Plebankiewicz, E.; Wieczorek, D. A SWOT Analysis of the Use of BIM Technology in the Polish Construction Industry. Buildings 2020, 10, 16. [CrossRef]

75. Koseoglu, O.; Keskin, B.; Ozorhon, B. Challenges and Enablers in BIM-Enabled Digital Transformation in Mega Projects: The Istanbul New Airport Project Case Study. Buildings 2019, 9, 115. [CrossRef]

76. Oke, A.; Kineber, A.; Albukhari, I.; Othman, I.; Kingsley, C. Assessment of Cloud Computing Success Factors for Sustainable Construction Industry: The Case of Nigeria. Buildings 2021, 11, 36. [CrossRef]

77. Afolabi, A.; Ibem, E.; Aduwo, E.; Tunji-Olayeni, P.; Oluwunmi, O. Critical Success Factors (CSFs) for e-Procurement Adoption in the Nigerian Construction Industry. Buildings 2019, 9, 47. [CrossRef]

78. Silverio-Fernandez, M.A.; Renukappa, S.; Suresh, S. Evaluating critical success factors for implementing smart devices in the construction industry. Eng. Constr. Arch. Manag. 2019, 26, 1625-1640. [CrossRef]

79. Ullah, F.; Thaheem, M.J.; Sepasgozar, S.M.E.; Forcada, N. System Dynamics Model to Determine Concession Period of PPP Infrastructure Projects: Overarching Effects of Critical Success Factors. J. Leg. Aff. Disput. Resolut. Eng. Constr. 2018, 10, 04518022. [CrossRef]

80. Liu, G.; Zheng, S.; Xu, P.; Zhuang, T. An ANP-SWOT approach for ESCOs industry strategies in Chinese building sectors. Renew. Sustain. Energy Rev. 2018, 93, 90-99. [CrossRef]

81. Lu, W. Improved SWOT Approach for Conducting Strategic Planning in the Construction Industry. J. Constr. Eng. Manag. 2010, 136, 1317-1328. [CrossRef]

82. Khojaste-Sarakhsi, M.; Ghodsypour, S.H.; Ghomi, S.F.; Dashtaki-Hesari, H. Energy efficiency of Iran buildings: A SWOT-ANP approach. Int. J. Energy Sect. Manag. 2019, 13, 726-746. [CrossRef]

83. Zhang, L.; Guo, S.; Wu, Z.; Alsaedi, A.; Hayat, T. SWOT Analysis for the Promotion of Energy Efficiency in Rural Buildings: A Case Study of China. Energies 2018, 11, 851. [CrossRef]

84. Nguyen, P.T. Application of Swot for Construction Company Quality Management Using Building Information Modelling. J. Mech. Contin. Math. Sci. 2018, 13, 25-33. [CrossRef]

85. David, F.R. Computer-assisted strategic planning in small businesses. J. Syst. Manag. 1985, 7, $24-34$.

86. Sepasgozar, S.M.; Shirowzhan, S.; Loosemore, M. Information asymmetries between vendors and customers in the advanced construction technology diffusion process. Constr. Innov. 2021. [CrossRef]

87. The SPSSAU Project. SPSSAU (Version 20.0), Online Application Software. 2020. Available online: https://www.spssau.com (accessed on 21 April 2021).

88. Eisinga, R.; Grotenhuis, M.T.; Pelzer, B. The reliability of a two-item scale: Pearson, Cronbach, or Spearman-Brown? Int. J. Public Health 2013, 58, 637-642. [CrossRef] [PubMed]

89. Li, H.; Qiang, M.; Yumei, L.; Min, J. Analysis and Study on AHP -Fuzzy Comprehensive Evaluation. China Saf. Sci. J. 2004, 14, 86-89.

90. Ghorbani, A.; Raufirad, V.; Rafiaani, P.; Azadi, H. Ecotourism sustainable development strategies using SWOT and QSPM model: A case study of Kaji Namakzar Wetland, South Khorasan Province, Iran. Tour. Manag. Perspect. 2015, 16, 290-297. [CrossRef]

91. Nasab, H.H.; Milani, A.S. An improvement of quantitative strategic planning matrix using multiple criteria decision making and fuzzy numbers. Appl. Soft Comput. 2012, 12, 2246-2253. [CrossRef]

92. Nabi, B.G.R.; Hoveidi, H.; Jafari, H.R.; Karbassi, A.R.; Nasrabadi, T. Application of ozonation in drinking water disinfection based on an environmental management strategy approach using SWOT method. Iran. J. Environ. Health Sci. Eng. 2006, 1, 23-30.

93. Guan, X.Y.; Wang, S.L.; Gao, Z.Y.; Lv, Y.; Fu, X.J. Spatio-temporal variability of soil salinity and its relationship with the depth to groundwater in salinization irrigation district. Acta Ecol. Sin. 2012, 32, 198-206.

94. Smith, A.; Guo, D.L.; Wang, Y.A. An Inquiry into the Nature and Causes of the Wealth of Nations; Commercial Press: Beijing, China, 2003.

95. Porter, M.E. Competitive Strategy; New York Free Press: New York, NY, USA, 1980.

96. Hannan, M.T.; Freeman, J.H. The Population Ecology of Organizations. Am. J. Sociol. 1977, 82, 929-964. [CrossRef]

97. Wu, A.Q.; Jia, S.H. The research framework of foreign enterprise growth theory. Foreign Econ. Manag. $2002,2,2-5$.

98. Penrose, E.T. The Theory of the Growth of the Firm; Oxford University Press: Oxford, UK, 1959.

99. Nelson, R.; Winter, S. An Evolutionary Theory of Economic Change; Harvard University Press: Cambridge, MA, USA, 1982.

100. Prahalad, C.K.; Hamel, G. The Core Competence of the Corporation. Harv. Bus. Rev. 1990, 66, 79-91. 
101. Barak, S.; Javanmard, S. Outsourcing modelling using a novel interval-valued fuzzy quantitative strategic planning matrix (QSPM) and multiple criteria decision-making (MCDMs). Int. J. Prod. Econ. 2020, 222, 107494. [CrossRef]

102. Moazeni, K. Empowerment of the institutional-managerial structure by urban sustainable development approach and fuzzy QSPM. Teh. Vjesn. Tech. Gaz. 2016, 23, 17559. [CrossRef]

103. Shiehbeiki, S.; Abbaspour, M.; Monavari, S.M.; Arjmandi, R.; Lahijanian, A. Public Participation Role in Sustainable Urban Management by Quantitative Strategic Planning Matrix (QSPM). Int. J. Environ. Res. 2014, 8, 1309-1314.

104. Esmaeili, A.; Kahnali, R.A.; Rostamzadeh, R.; Zavadskas, E.K.; Sepahvand, A. The Formulation of Organizational Strategies Through Integration of Freeman Model, Swot, And Fuzzy Mcdm Methods: A Case Study of Oil Industry. Transform. Bus. Econ. 2014, 13, 602-627.

105. Tsai, P.H.; Chen, C.-J.; Yang, H.-C. Using Porter's Diamond Model to Assess the Competitiveness of Taiwan's Solar Photovoltaic Industry. SAGE Open 2021, 11. [CrossRef]

106. Knott, P.J. Does VRIO help managers evaluate a firm's resources? Manag. Decis. 2015, 53, 1806-1822. [CrossRef]

107. Lin, C.; Tsai, H.-L.; Wu, Y.; Kiang, M. A fuzzy quantitative VRIO-based framework for evaluating organizational activities. Manag. Decis. 2012, 50, 1396-1411. [CrossRef]

108. Sebestova, J.; Szkandera, I.; Bernatik, W. Analysis of stage of SMEs in Moravian-Silesian region by VRIO method application. E M Ekon. Manag. 2008, 11, 51-61. 